University of Louisville

ThinkIR: The University of Louisville's Institutional Repository

Electronic Theses and Dissertations

1931

\title{
The electro-deposition of the binary system copper-cadmium.
}

Allen Stratton Smith 1906-1966

University of Louisville

Follow this and additional works at: https://ir.library.louisville.edu/etd

Part of the Materials Chemistry Commons

\section{Recommended Citation}

Smith, Allen Stratton 1906-1966, "The electro-deposition of the binary system copper-cadmium." (1931). Electronic Theses and Dissertations. Paper 1954.

https://doi.org/10.18297/etd/1954

This Master's Thesis is brought to you for free and open access by ThinkIR: The University of Louisville's Institutional Repository. It has been accepted for inclusion in Electronic Theses and Dissertations by an authorized administrator of ThinkIR: The University of Louisville's Institutional Repository. This title appears here courtesy of the author, who has retained all other copyrights. For more information, please contact thinkir@louisville.edu. 
UHIVBRSITY OP LOUISVILLE

\title{
THE RLRCTRO-DEPOSTTION OF THE BTHAFY SYSTEM COPPER - CADUTUM
}

\author{
A Diesertation \\ Submitted to the Faculty \\ Or the Enduate Sahool of the University of Loulsville \\ In Partial Fulf11lment of the \\ Requiremente for the Degree \\ of llaster of selenoe
}

Departwent of Chomietry

By

Allen Stratton $\operatorname{Sin}_{11}$

1931 
TABLE OP COHTRMTS

\section{Ohapters}

I. Introduction

Historienl

Page 1

Theoretioal

2

II. Experimental

Prolininary

Apparatus and Proodure

Romalto

Final

Apperatus and Procedure

Date and Reaults

28

III. Conoluatons 43

IV. BIbllography

44

\section{List of rables}

I. Interwediate Conetituents of the Syatem ou-Cd

II. Single Potentials of Hetals Towaxd

Solutions wth Hemel Ion Conoentration

III. Inmatabli1ty Conetents for the Complex

Cyantdes of Copper and Cadmiun

IV. Stook Solutions

V. Conposition of Plating Solutions

VI. Bxperimentiel Data 
VIII. Effoet of Potansium Cyanide 26

IX. Iffect of Sodium Blaulphite Addition sI

X. Effect of Gurrent Denst ty 34

XI. Fffect of Fouperature 37

XIX. Bffect or Dilution 40

List of Curves

F18. I. Potential-Composition Curves 5

2. Copper-Cadmitu Conotitution Diagram $T$

3. Current Density-Potential Curve: 10

4. Bffoet of $\mathrm{KCl}$ on Discharge Potentiel 13

5. Effect of kON Aadition 15

7. Wiring Diagram of the Apparatus 20

8. Potential-rime curves $22-1$

9.Blectrode Bfflelendes 22-B

10. Single Potential of Alloy Deposits 24

11, 22. Rffect of KCI 28,29

13, 14. Erreat of $\mathrm{NaHSO}_{3} \quad 32,33$

15, 16. Brfoot of Current Denalty 35,36

17, 18. Bffect of Temperature 38, 39

19, 20. Iffect of Metal Content 41, 42 


\section{I-IHTRODUCTION}


HISTORTCAI.

It 1s lnown that under certain oonditions it is posalbie to depontt olectrochemically two or moxe motals simultaneously from tholi mutwin solution. The only alloy which 1s extenatrely deposited comberelally is brase (I). al though bronses (2) and load-tin ( 3 ) alloys have been - lectrodeposited, the latter on a mall oomereial scale by the U. S. Vavy Department. Nontion $1 \mathrm{~s}$ also made in the Ilterature of eleotrodepostted alloys of niokel-magnealum (4), Iron-8ine (5), sino-nickel (6), ativer-gola (7), silveroudiniue (8), niakal-oopper (9), nlokel-1ron (10), tincadmin (11), and cobult-ntokel (12).

Allog deposition is abject to numerous undefined variables, and although oertain general prinelples aro known their appliteation cemanda conatelerable weseareh whioh has not been forthooring, roaviting in ouplrical bases for coneretal allog doposition. The sirst paper of this series on alloy deposition, prepared for the expressed purpose of placing the electrodeposition of the present commercial alloys on aclentiflo beclss and for the development of new, comerelally userul alloys by study of thooretion princlples and their Intelilgent application, will appoar shortiy in the Journal of the Amerioan Eleotrochemioal Sooloty (13):

Nivmbers in parentheses refor to bibllography at ond of volume. 
THEORETICAL

Alloys of copper contalning smil amounts of cadminm, up to 1.8 percent, hure been used in the form of wre for electrical tranantiaglon. Such alloye have an -lootrionl conduotivity greater then any other alloy of

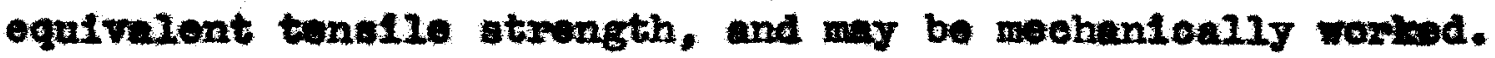
The tenalie strength of hard drawn oopper-oadmiva wire, .001 inoh in alamoter, containing 1,2 peroent oadmium is 100,000 pounds per aquare Inch, while the conduetivity of the annealed wire is 91 pereent.

The phystad properties and micro-constituents of oopper-eactulum elloy: prepared from the pure metals have been determined. The tables prepared by A. Purhin (14) when the preaenoe of the three pheses: $\mathrm{Cd}_{2} \mathrm{Ou}$, eolld walutions of Ca In $\mathrm{Cd}_{8} \mathrm{Cu}$ and of $\mathrm{Cd}_{2} \mathrm{Cu}$ in $\mathrm{Cu}$. From a study of the conatitution of cadiufu-copper alloye, C. Jenkins and D. Henson (15) atate that four intermediate constituents appear to exist: $\mathrm{Cu}_{2} \mathrm{Od}, \mathrm{Cu}_{4} \mathrm{Ca}_{3}, \mathrm{Gu}_{2} \mathrm{Od}$, and $\mathrm{CuCd}_{3}$. The extstanoe has also been eatabliched of metatablo condition in wioh the $\alpha$ constituent 18 suppresesd and metastable outeotic included. Up to 60 atomic percent copper the alloya are white; wth 68 atomic peroent copper they are bright yellow; with 80 atomle pereent copper, rose colored; and with 90 atomito percent oopper, red (copper color). Tho hardness with the concentration of copper, reaching a maximum at 33 
atomio peroent copper. Further addition of copper makes thex brittle. Between 40 and 50 atomic percent coppex the brittieness ia such that they can be broken by hand. With 68 atomis percent thay again become very hard and remain wo up to 80 atemis pereent copper when the haxdiness again decroavea, gradunliy approaning that of puxe copper. since oopper-cactuatun alloya for use in eleotrical tranmisalion contain only mall amounts of cadmium, motullurgleal methods of preparation would be more cocnomical. Alloy: contalning a hlgh percentage of cadmiun would be commerolally useful for corrosion rosiating coatings. Pure cadnitum deposits take well on all motals, are highiy reslatant to atmo:phoxto corrostion, and take high pollsh. They are of a oolor approaching aliver, but retain thelr poliah without tarnishing longer then allver, or allver alloys. They are superior to tin as rust rosisting agents for Iron and steol, and form a highly efflelent protective couting for aluminum.

A consideration of corrosion resisting alloys leads to the soncluation that to Increaso the resietance to corrosion of any buse metal there should be alloyed with it another metal which is moro rosiatent to corrosion and wich a solld solution with the wetal whose resiatinoe to corrosion It is desired to enhance. In constdering o copper-admium alloy, copper fulf1lls these conditions belng nobler than cadmivan, and forming solid solutions (16).

An alloy of two metals is coramonly heterogeneous 
In that it consiats of an aggregate of crystals of two or mowo afferent lands, containing the constituent metals in difforent proportions. In sone caes the whole alloy consista of only one apeoles of cryatal, 1.0. a Angle phace. In the forwer ease, where there are two of more phases, the equilibrium potential of the alloy is determined essentialiy by the baseet phese present. The chomical behaviox of an alloy ia Inalcated by ite equilibrium potentlal. Thus it vill roplece trom solution metal which has a moxe postive equilibrium potential against that solution. Stmilarly, it will tend to replece hydrogen from an acid if its potential 1s baser then that of hydrogen againgt that acid. In each case it is the besest phase which will go into solution. F1g. I (17) abows potential-composition curves for three types of alloys. In all eases a represents the baser motal and $B$ the more noble. Curve I represents two metels wioh are insoluble in the solld state and form an intermetallic compound $\mathrm{A}_{2} \mathrm{~B}_{3}$ * Curve II corresponda to an alloy whioh does not form a complete series of aolld solutions. Curve III is an example of two metals which are mutualiy soluble in the solld state in all proportions. The system copper-cadmitum is an example of Curve II forming solld solutions of $\mathrm{Cu}$ in $\mathrm{Cu}_{2} \mathrm{Cd}$ and $\mathrm{Cu}_{2} \mathrm{Cd}$ in $\mathrm{Cu}$, wa wa several intermediate constituents. 


\section{Fral}

Potential-Composition cumes 


\section{Table I}

Interwediate Constituents of the System Cu-Cd

\begin{tabular}{|l|cc|cc|}
\hline \multirow{2}{*}{ Compound } & \multicolumn{2}{|c|}{ Woight Percent } & \multicolumn{2}{|c|}{ Atomic Percent } \\
\cline { 2 - 5 } & $\mathrm{cu}$ & $\mathrm{cd}$ & $\mathrm{cu}$ & $\mathrm{cd}$ \\
\hline $\mathrm{Cu}_{2} \mathrm{~cd}$ & 53.2 & 46.8 & 66.6 & 38.4 \\
$\mathrm{Cu}_{4} \mathrm{Cd}_{3}$ & 43.0 & 57.0 & 67.1 & 42.9 \\
$\mathrm{Cu}_{2} \mathrm{Cd}_{3}$ & 27.4 & 72.6 & 40.0 & 60.0 \\
$\mathrm{Cu} \mathrm{Cd}_{3}$ & 15.9 & 84.1 & 25.0 & 75.0 \\
$\mathrm{Cu} \mathrm{Gd}$ & 22.1 & 77.9 & 33.3 & 66.7 \\
\hline
\end{tabular}

* Hot certain

Reforence to Table I and FIg. 8 will show that an alloy contalning approxtmately 53 percent copper and 47 percent oddmium will give a binary compound having a large proportion of the intermediate compound $\mathrm{Cu}_{2} \mathrm{Cd}$ wioh forms a solld solution with Gu. It is the purpose of this thesis, then, to electrochemically deposit a copper-catmiun alloy containing approximately 55 percent copper. The above deduotions are based entirely on the essumption thet the electrodeposited alloy ha mieroatrueture analogous to that of the binary aystem prepared from the pure metals, which is not definitely known.

Simultaneous deposition of two tals is, in general, only possible when the single potentials of the two metals 110 very close together, unless olther the deposition of the beser metal is constderably depolarized or the concentration of the lons is varied by regulation of current 


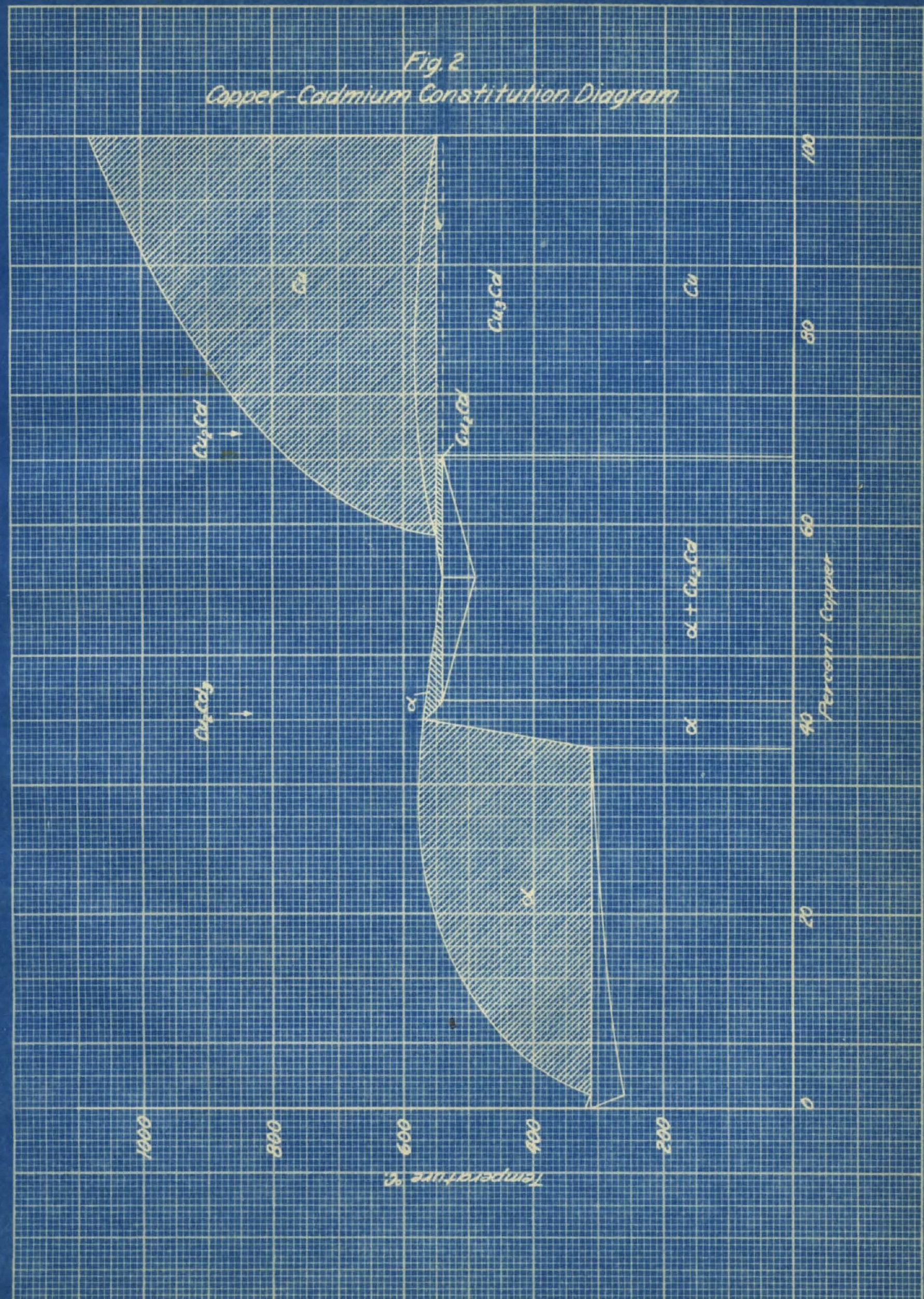


density, formation of complex lons or addition of the lon. Motels belon hydrogen in the electromotive series on be depoatted fram ald aolutions of th a -high cathode erfleteney because the single potential of the motal in a solution normal with respect to metal and hydrogen lons is higher than that of hydrogen. Tho deposition of hydrogen w11. therefore require a greatex potential than would be nocessary to depoalt the metal, and honce w111 deposit with a high offletenoy. Whis is shown by the Mernst formula whioh explains the origin of eleotromotive foree on the basis of osmotic and selution pressure relations.

$$
B=\frac{R T}{n F} \log _{e} \frac{P_{8}}{P_{0}}
$$

Where

$$
\begin{aligned}
& B=\text { angle electrode potuntial } \\
& R=\text { gas constant expres.3ad in velts, coulomba } \\
& P=\text { elootroohomical equivalent } \\
& n=\text { valence of the metal lons } \\
& P_{\mathrm{B}}=\text { eleotrolgtio aolution pressure } \\
& P_{0}=\text { omotic pressuro } \\
& \text { T =bsolute temperature of solution } \\
& \text { Since oumotic pressure is proportional to the }
\end{aligned}
$$
effective coneentration, $P_{0}=K C$.

$$
B=\frac{\mathrm{RP}^{\mathrm{P}}}{\mathrm{nP}} \log _{\mathbf{0}} \frac{\mathrm{P}_{\mathbf{B}}}{\mathrm{XC}}
$$

Stnoe $P / K$ is anstant at any given temperature, the single potentiel is 


$$
E=E_{0}+\frac{R P}{n F} \log _{\theta} C
$$

Where

$$
\begin{aligned}
& B_{0}=\text { eleotrelytio potontial } \\
& C=\text { concentration in gram lons por } 11 \text { tor }
\end{aligned}
$$

For two motale to be simultaneously deposited, their cathode potentials unet be equal or 110 vory close togethar. The single potential of the two motals do not 110 olose together as may be seen in Table II (18).

\author{
Table II \\ Single Potentials of Motals Toward Solutions \\ wth Noxmal Hetal Ion Concentration \\ Hetal \\ Cadming \\ Hydrogen \\ Copper \\ Volta* \\ $-0.40$ \\ 0.00 \\ 0.34 \\ * Based on normal hydrogen electrode as zero.
}

Ir, however, the concentration of metal lons is decreased, 0.8 . by dilution, or the concentration of hydrogen Ions is deoreased, 0.B. by addition of an actd, the potential of the motal way decrease while that of hydrogen Inereases and the two approach each other. Whon the potentials become -qual, atmulteneous deposition of the metal and hydrogen becoues posatble. If the single potential were the only ractor geverning deposition, defintte results could be predioted but eurrent density (FIg. 3) (19), polarization, 


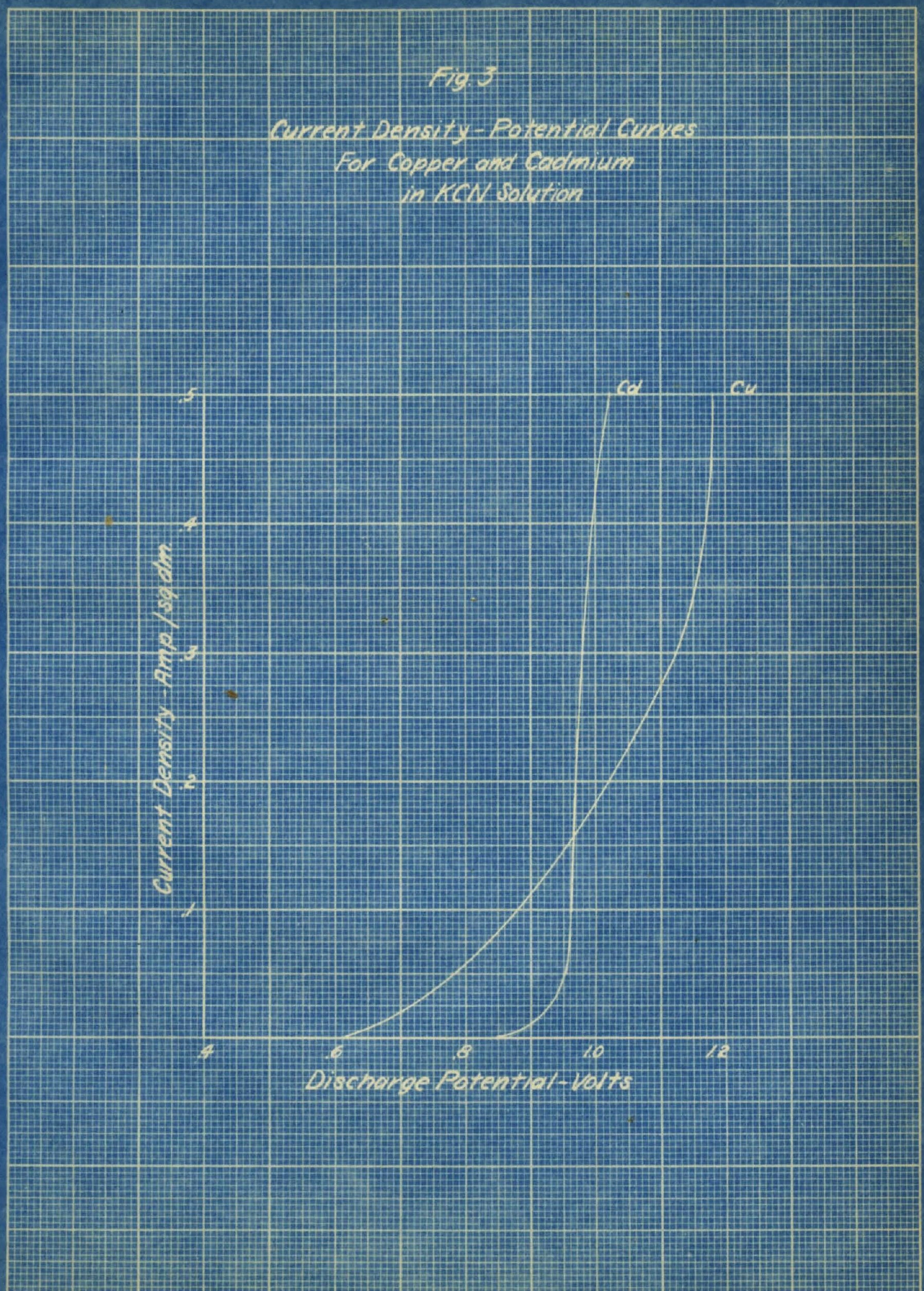


overvoltage and temperature have also been shown to be important ractors.

The potentials of copper and cadmium 11 e relativeIf far apart so taht it is Impossible to deposit thom aimulteneously from solution in whioh their lonic coneentrations are high. A low concentration of their lons mag be obtained by extreme dilution and by the nae of complex ion solutions. The complex cyenides of copper and sine are used In brass plating, and those of copper and cadmlum should bo applicable in the proposed copper-cadntum alloy deposition. Reference to the Ionle equetions (20) shows the sources of the lons and Fable III (2I) indicates the relative anounts of each which will be present.

$$
\begin{aligned}
& 2 \mathrm{~K}^{+}+2 \mathrm{CN}^{-} \\
& \text {a. }\left(\mathrm{CuCH} \rightleftharpoons \mathrm{Cu}^{+}+\mathrm{CH}^{-}\right)+\left(2 \mathrm{gKCH}+9 \mathrm{H}_{2} \mathrm{O}\right.
\end{aligned}
$$

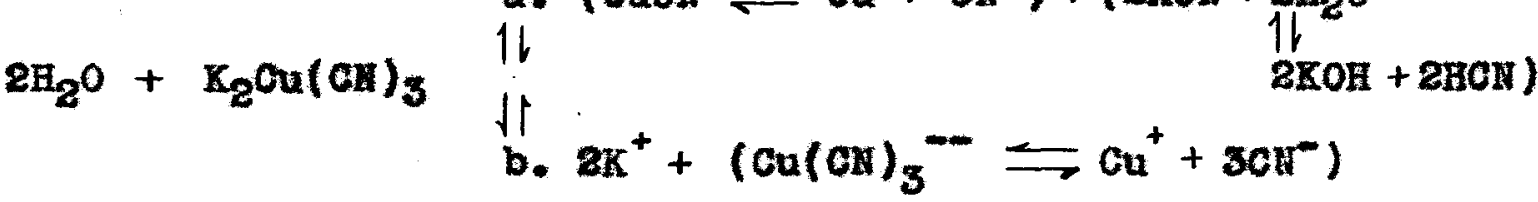

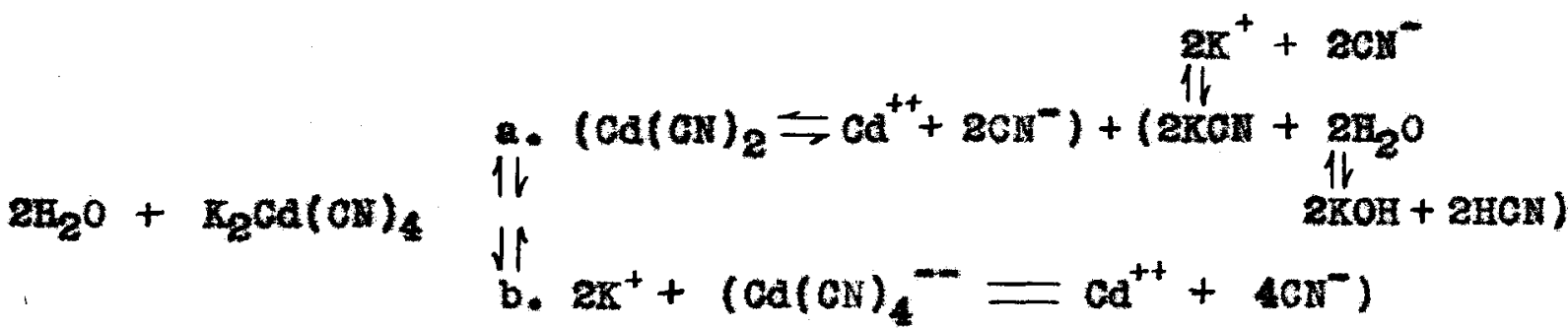


Table III

Inotability Constants for the Complex Cyentde of cu and $\mathrm{Cd}$

\begin{tabular}{|c|c|c|}
\hline Compound & Instabllity Conatant & $\begin{array}{l}\text { Cone. of metal } \\
\text { ion in } 1 \text {. } 301 .\end{array}$ \\
\hline$\pi_{2}\left(\mathrm{Cu}(\mathrm{ON})_{3}\right)^{*}$ & $\frac{\left(\mathrm{Cu}^{+}\right) \times\left(\mathrm{CH}^{-}\right)^{3}}{\left(\mathrm{Cd}(\mathrm{CH})_{4}^{--}\right)}=0.5 \times 10^{-27}$ & $3.7 \times 10^{-8}$ \\
\hline $\mathrm{K}_{2}\left(\mathrm{Cd}(\mathrm{CH})_{4}\right)$ & $\frac{\left(\mathrm{Ca}^{++}\right) \times\left(\mathrm{CH}^{-}\right)^{4}}{\left(\mathrm{Ca}(\mathrm{CH})_{4}^{--}\right)}=1.4 \times 10^{-17}$ & $8.0 \times 10^{-5}$ \\
\hline
\end{tabular}

*The correct formula for the copper complex is $\mathrm{xCu}(\mathrm{CN})_{2}$ ae deterained by hydrogen ion measurements (22). It is asaumed, however, that/the compound $\mathrm{K}_{2} \mathrm{Cu}(\mathrm{CN})_{3}$, it Is more stable than the cadeation complex.

The fact that the addition of oyanide roduces the concentration of copper lons more rapidiy than that of cadralum lons is the basis for the supposition that copper and cadnium can be simultaneously deposited since, as the concentration of copper lons decreases, its potentlal is reduced and approaches that of cadmium. Fig. 4 shows the effect of KCH on discharge potential (23). Copper and cadmiun may be separated in a solution containing less than .25 mole of free $\mathrm{KCN}$ per 11 ter and more than .275 mole. In the firat solution the diseharge potential of copper is less than that of cadmlum and therefore would be preferen- 


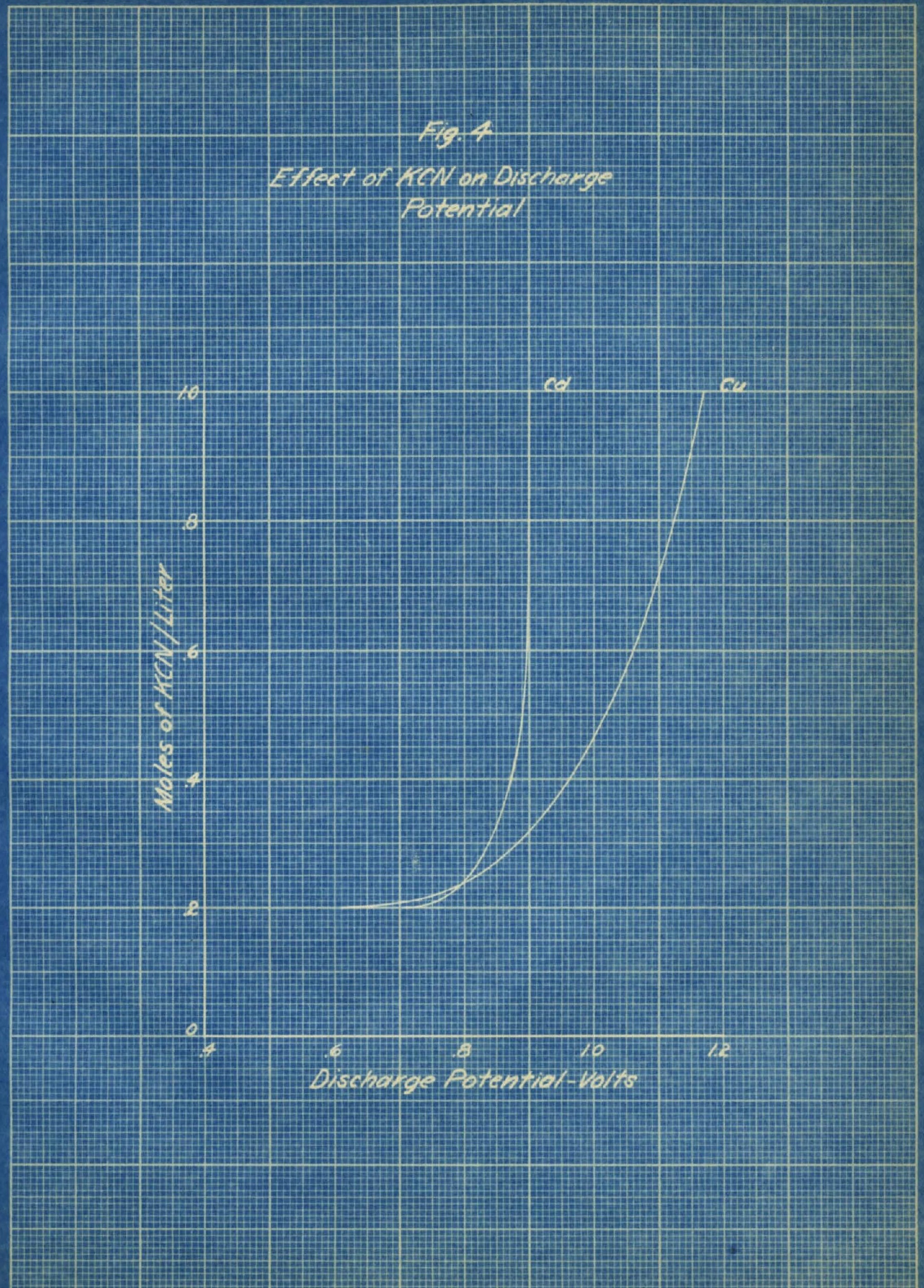


tilly deposited before copper ince its disoharge potentlal 18 lower than that of copper.

F1g. 5 (17) ahows graphionlly the effect of the addition of $\mathrm{KCN}$. The potentials of both oadmium and copper are reduced, 1.0. made more negative, by addition of $\mathrm{KCN}$ but that of copper is reduced more raplaly than that of odmium so that the potential of the former gradually appronches, equala and becones less then the lattor. At the point were the potentials of copper and cadmium beoome equal simultanoous deposition $1 \mathrm{~s}$ possible.

Depolarization of the deposition of the baser metal, 1.0. cadmium, may also cause the equilibrium potontial. of the two metals to become equal or nearly equal, so that afmultaneove deposition may be offeoted. It is intendod to study the conditions by which almultaneous deposition of copper and cadmin may be obtained in the desired proportions. 


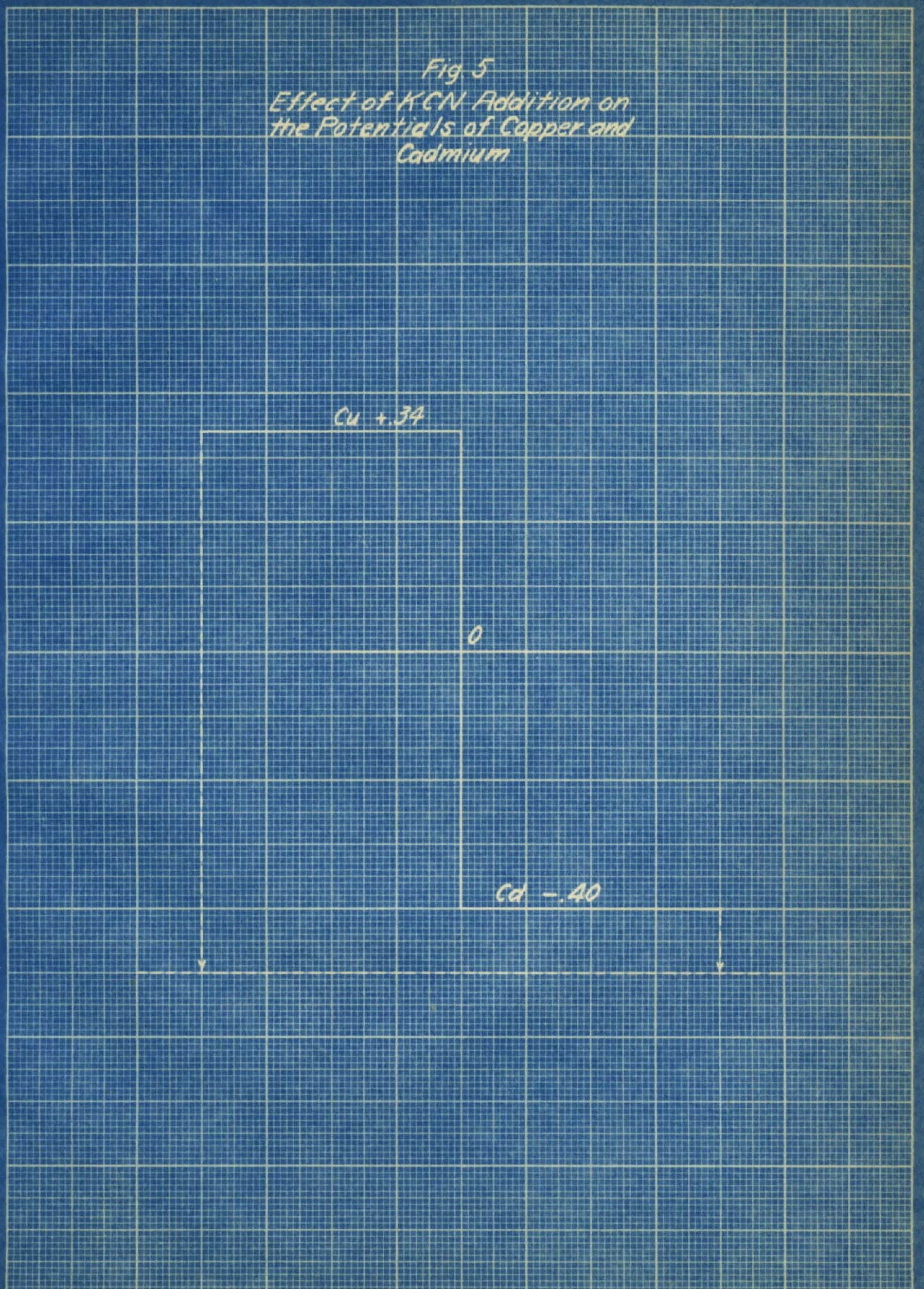


II - EXPERTIGATRAL 


\section{Prolininary}

Appartus and Procodure

In order to determine from that type of beth a dopost containing copper and cadmium could be obtalned, ctook solution of the complex copper cyanldes and the complex oadmitur oyantde wore wade up and these were used to prepare baths of different motal Ion concentrations and different copper-oadmitun ion ratios.

Table IV

Stook Solutions

\begin{tabular}{|c|c|c|c|c|c|}
\hline Solution & Selt Used & $\begin{array}{c}\text { Concentra- } \\
\text { tion }\end{array}$ & potal $\mathrm{KCN}$ & $\begin{array}{c}\% \\
\text { Excess }\end{array}$ & $\begin{array}{l}\text { Metal Ion } \\
\text { Content }\end{array}$ \\
\hline $\begin{array}{l}\mathrm{KOu}(\mathrm{CN})_{2} \\
\mathrm{~K}_{2} \mathrm{Cd}(\mathrm{CN})_{4}\end{array}$ & $\begin{array}{c}\mathrm{CuCH} \\
\mathrm{Ca}(\mathrm{CH})_{2}\end{array}$ & $\begin{array}{l}40.2 \mathrm{~g} . / 1 . \\
46.5\end{array}$ & $\begin{array}{l}66.0 \mathrm{~g} \cdot / 1 . \\
76.9\end{array}$ & $\begin{array}{l}258 \\
169\end{array}$ & $\begin{array}{l}28.5 \mathrm{gm} / \mathrm{h} \\
31.8\end{array}$ \\
\hline
\end{tabular}

Four cells wexe ued connected in parallel with onrbon anodes and nickel enthodes. Miokel was used as it had a low overroltage and wes but slightly soluble in concontrated nttrie acid, In which the doposit was dissolved for analyals, since sufficient pletinum for use as cathodes was not avaliable. A eurrent denal ty of 0.3 ampere per equare decineter wes malntalned at the oathode.

A qualitative analysis only was perfomed for copper in the deposit. The cathodes were washed and dissolved in 50 0.0. Of conoentrated nitrio acid. The solatlons were evaporated to a rolume of 5-10 c.c., diluted 
wth 25 c.0. of distilled water, neutrallsed with allute amontum hydroxide and made acldic with acetic acid. 5 c.c. of the solutions were tested wth potassium farrocyanide, ane arop belng added, allowed to atant for 2-3 minutes, then 3 c.c. more added. A pink to red coloretion indicated the Indicated the presence of copper. The Intensity of color In both the amonia and potassium ferrooyanide solutions was compared and the relative amounts of copper preaent in each deposit was thus fudged. A atumary of the data obtained in the preliminary work follows.

Preliminary Results with

Several Hetal Ion Ratios and an Addition Agent

Solution No.

1

2

3

4

Hetal ion ratio ou

90

70

50

30

cd

10

30

50

70

Totel motal ion content 88.75

29.40

30.10

30.7

Coppor analysis

Present Mone

None

None

Seme solutLons as above; $22 \mathrm{~g} \cdot / 1$. added to each one of $\mathrm{NaHSO}_{3}$. Solution No. 5 6 7 8 Copper Anaiysis Present Hone None None 
Same solutions as above: $12 \mathrm{~g} \cdot / 1$. of $\mathrm{NaHSO}_{3}$

additional added to each one.

Solution Ho.

10

11

12

Copper analysis

None

Prosent frone

Hone

Solution Ho.

15

14

15

16

Motal Ion Ratio

Cu 60

60

60

60

cd 40

40

40

40

Total Ietal Ion Content

89.8

29.8

29.8

$20 \mathrm{~g} \cdot / 1$.

$\mathrm{NaHSO}_{3}$ added, $\mathrm{g} \cdot 1 \mathrm{C}$.

0.0

18

24

B

Copper Analyala

Trace

Hone

none

Present

Solution No.

17

18

19

20

Motal Ion Ratio

Cu 60

60

60

60

cd 40

40

40

40

Total Metal Ion Content 25

25

20

$20 \mathrm{~g} \cdot 1 / \mathrm{s}$.

NaHSO 3 added, $\mathrm{E} \cdot 1 / 1$.

0

10

0

B

Copper Analyals

Hone

Trace

Trace

Present

It is evident from the proliminary results that Iow metal $10 \mathrm{n}$ concentration and the presence of $\mathrm{NaHSO}_{3}$ (which reduces the anount of free $\mathrm{KCH}$, wee explenation under "Rffect of $\mathrm{NaHSO}_{3}$ Addition", page 30 ) are to be desired. A bath for the experimental work was therefore selected containing copper and cadmium in the ratio of 60:40 and a total metal Ion concentration of 20 grams por liter. 
Exporimental Work - Pinal

Apparetue and Procedure

The oell usod was orystallising dish. Cast anodes of copper and cadnitum were employed, and a cathode consieting of a sill platinum oruclble one and throeelghth Inches in height, threo-fourths inch in dianeter at the bottom and ono and one-eighth inokes at the top. A Leeds and Horthrup potentiometer hookup was used for potential meanuments with a saturated chlomel reference - lectrode by three salt agar-agar bridgen to the nelghborhood of each electrode. The current density at the cathode and unode was kept equal and the ourrent donsity at each anocie was one-half of that at the cathode whioh was 0.3 umpere per equare decimeter. A wiring alagram of the instrumonts and epparatus is shom in $\mathrm{FIg}$. 7 .

The composition of the four solutions used in the different runs is given in Table $v$.

Table V.

Coraposition of Plating Solutions

\begin{tabular}{|c|c|c|c|c|}
\hline Solution Ho. & $\mathbf{I}$ & II & III & $\mathbf{I V}$ \\
\hline Cucx $\quad$ g.1. & 16.93 & 16.98 & 16.98 & 21.17 \\
\hline $\operatorname{cat}(\mathrm{CH})_{2} \mathrm{~g} \cdot 1 \mathrm{1}$ & 11.70 & 11.70 & 11.70 & 7.31 \\
\hline $\operatorname{Kan} \quad \mathrm{g} * / 1$ & 43.20 & 44.90 & 49.20 & 48.34 \\
\hline Porcent excoss $\mathrm{KCH}$ & 100.00 & 105.00 & $12 \% .00$ & 128.00 \\
\hline Cu/Ca Ratio & $60: 40$ & $60: 40$ & $60: 40$ & $60: 20$ \\
\hline Total Metal Ion Content, $8 \cdot / 1$ & 20.0 & 20.0 & 20.0 & 20.0 \\
\hline
\end{tabular}




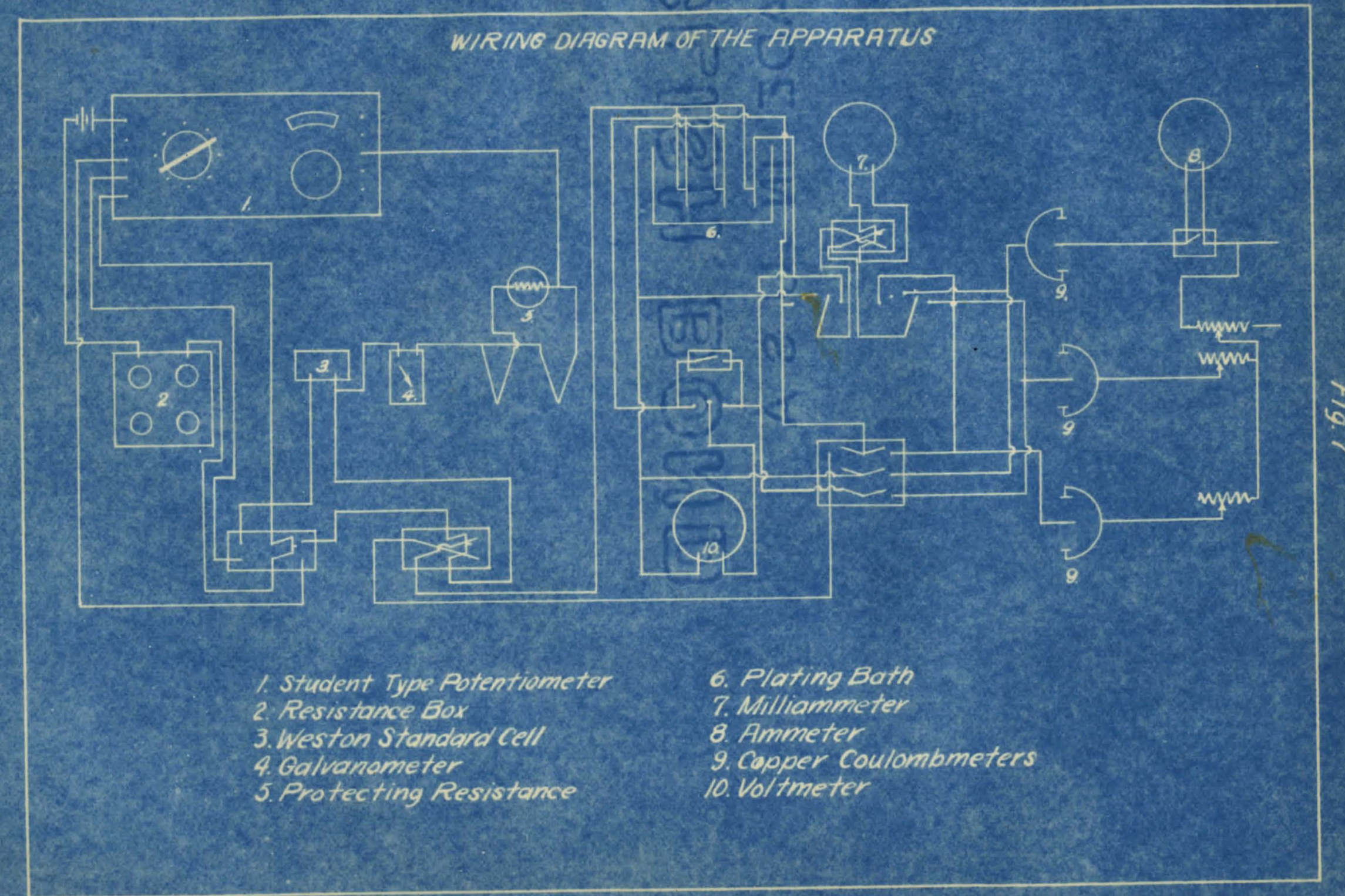

$\frac{2}{6}$ 
Bach run wa approxtmately two hours in length. Ten minute readings were taken of the eurrent at the - lectredes and in the 2ine, and the potential of the - lectrodes in the solution with the cument elowing. single potentials of the electrodes were also measured before and after ench run without the current flowing. Gopper coulometers were used in each electrode clreult to oheck the total quantity of eurrent passed.

The olectrodes and coulometer outhodes were removed from the cells after the runs, washed with water, aloohol and other, dried in a dessicator and weighod. The deposit on the platinum cathode wa disolved in $1: 2$ Mitite cold and the copper vas deterruined by the mothod in scott's "Teohnical Anniysts", page 193. Cadntum was taken by differenos. Galoulations wore made to determine mode and cathode efflciencies. Dta sheots are given together Ita ourvea showing the variation of olectrode potentials with then, single potentlal withoopper content of the dopout. and the efflciencies with copper content. Further expertmonts were made to determine the effect of sodiun bleulphite. In the following pages, the observed results are discussed and presented in tabular and graphical form. Agltation was not unod alnoe it was known from provious work to be of no ralue (13). 
male $\mathbf{r}$

Expoximanton 1 Date

\begin{tabular}{|c|c|c|c|c|c|c|c|c|c|}
\hline \multirow{3}{*}{$\begin{array}{l}\text { Run } \\
\text { Ho. }\end{array}$} & \multicolumn{3}{|c|}{ Efrtatonotes } & \multirow{3}{*}{$\begin{array}{l}\text { Poroent } \\
\text { Ou in } \\
\text { Deponit }\end{array}$} & \multirow{3}{*}{$\begin{array}{l}\text { Sotan } \\
\text { Kot } \\
\mathbf{E} \cdot / 2 .\end{array}$} & \multicolumn{3}{|c|}{ Potentind with ourront } & \multirow{3}{*}{$\begin{array}{c}\text { Chervoter } \\
\text { of } \\
\text { Deportt }\end{array}$} \\
\hline & \multicolumn{2}{|c|}{ Anoder } & \multirow[t]{2}{*}{ Cathode } & & & \multicolumn{2}{|c|}{ Anodes } & \multirow[t]{2}{*}{ Onthode } & \\
\hline & Gu & $\mathrm{cd}$ & & & & $\mathrm{ou}$ & od & & \\
\hline 4 & 68.9 & 125.9 & 76.4 & 30.5 & 47.2 & 2.6225 & 0.8580 & 2.0870 & \\
\hline 5 & 201.9 & $117 \cdot 6$ & 77.5 & 25.98 & 53.8 & 0.4685 & 0.9650 & 2.0375 & Snooth \\
\hline 6 & 68.7 & 110.02 & 71.9 & 18.08 & 53.8 & 4.4760 & 0.8780 & 8.1635 & $\begin{array}{l}\text { B11aterad } \\
\text { Cxay }\end{array}$ \\
\hline 7 & 10.15 & 116.7 & 33.0 & 5.69 & 58.2 & 1.8125 & 0.9000 & 1.4445 & Rough \\
\hline $\mathbf{a}$ & 62.6 & 111.8 & 63.5 & 21.98 & 53.8 & 4.4865 & 0.9440 & 2.2856 & $\underset{\text { exay }}{\text { strenled }}$ \\
\hline 9 & 61.8 & 129.8 & 79.4 & 28.69 & 59.8 & 4.4830 & 0.8825 & 1.7100 & $\begin{array}{l}\text { Gooth } \\
\text { Gery }\end{array}$ \\
\hline 10 & $77 \cdot 4$ & $204 \cdot 8$ & 67.2 & 19.86 & 54.2 & 0.2885 & 0.2485 & 2.2240 & smath \\
\hline 12 & 55.7 & 123.8 & $97 \cdot 2$ & 89.05 & 49.2 & 5.0615 & 0.6515 & 1.0000 & 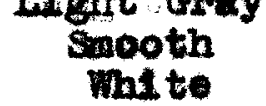 \\
\hline 12 & 120.0 & $127 \cdot 4$ & 65.2 & 6.30 & 68.3 & 0.5440 & 0.9450 & 8.345 & Stroaked \\
\hline 18 & 88.5 & 109.4 & 70.8 & 9.92 & 58.3 & 4.8280 & 0.8480 & 2.2875 & suopoth \\
\hline 14 & 41.3 & 78.7 & 89.0 & 38.40 & 48.3 & 0.9935 & 2.3000 & 8.5200 & Snooth \\
\hline 15 & 75.4 & 116.7 & 185.8 & 58.4 & 48.5 & 3.8075 & 0.4880 & 1.8730 & $\begin{array}{l}\text { Smooth } \\
\text { Ye110w }\end{array}$ \\
\hline
\end{tabular}




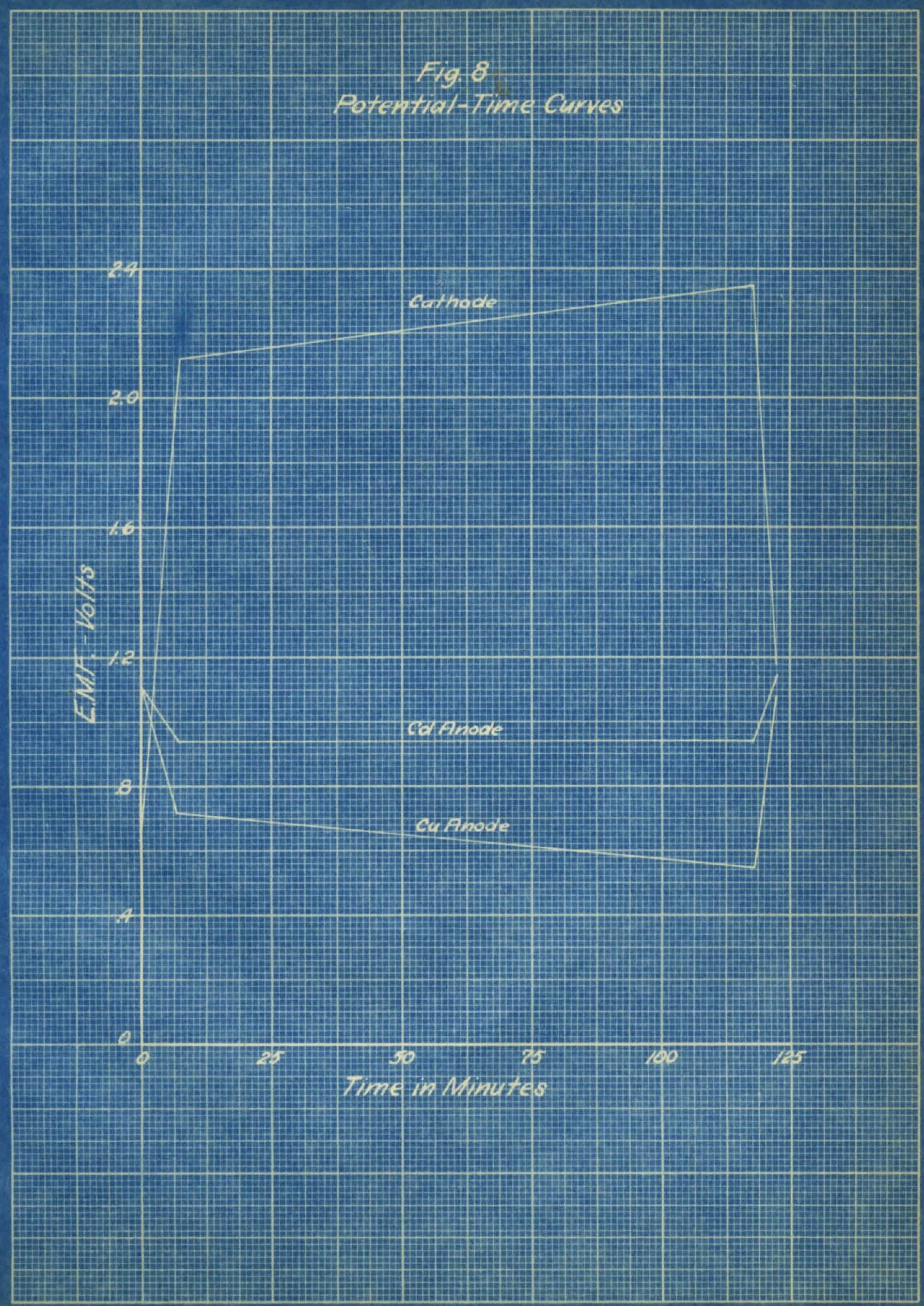


Fig, 9

Electrode Efficiendies

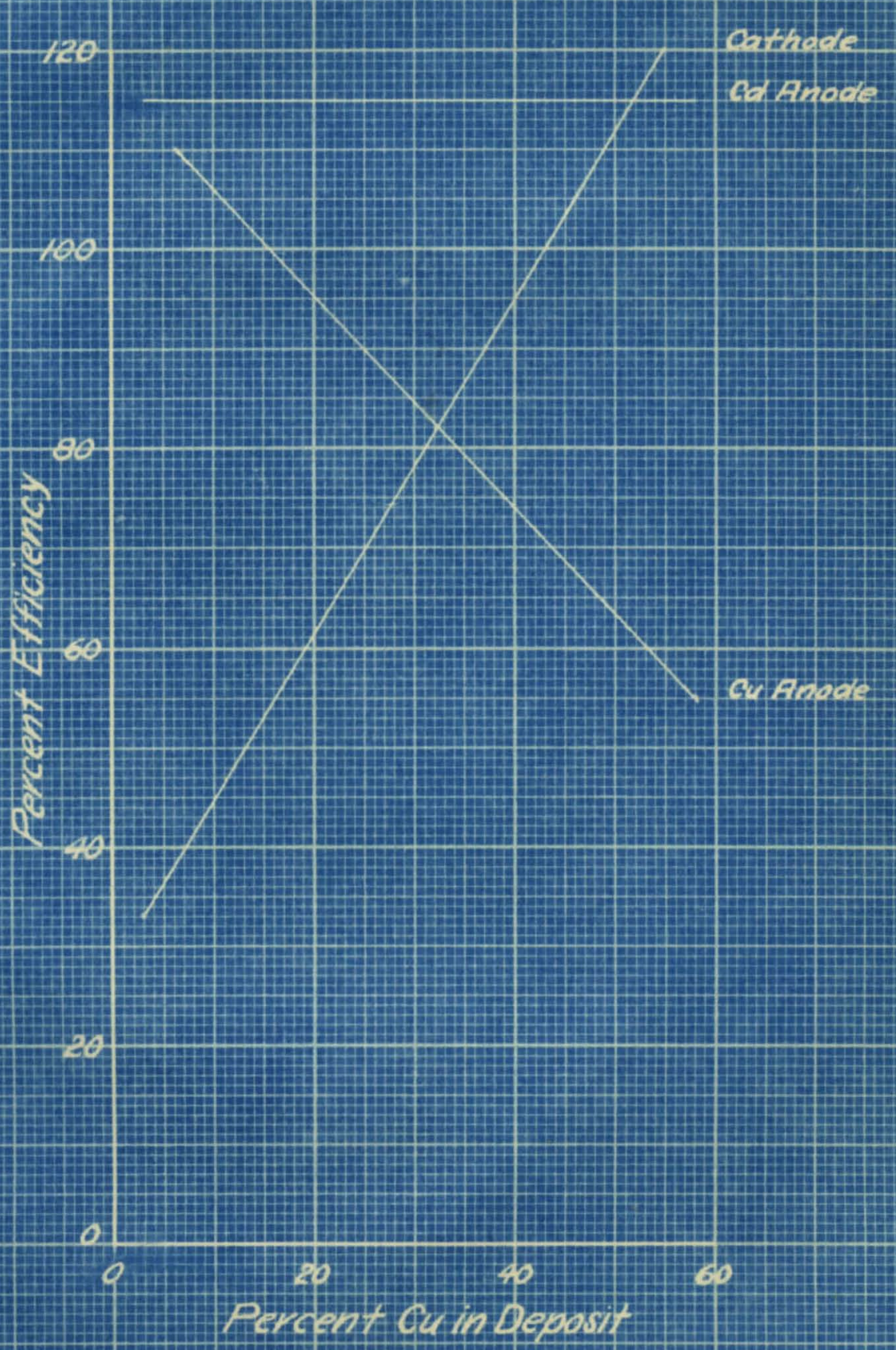


Table VEx

Single Potential of Alloy Deposits

\begin{tabular}{|c|c|c|c|c|}
\hline Run No. & Z.Y.F. & $\begin{array}{c}\text { E.t.F. of Reference } \\
\text { Eleotrode }\end{array}$ & $\begin{array}{l}\text { Single } \\
\text { Pot. }\end{array}$ & $\begin{array}{l}\text { Percent } \\
\text { Cu }\end{array}$ \\
\hline 5 & 1.1310 & .5260 & .6050 & 25.98 \\
\hline 6 & 1.1240 & .5264 & .5976 & 13.02 \\
\hline 7 & 1.0865 & .5264 & .6261 & 3.69 \\
\hline 8 & 1.0930 & .5266 & .5664 & 21.92 \\
\hline 9 & 1.1235 & .5863 & .5972 & 23.69 \\
\hline 10 & 1.1160 & .5266 & .5894 & 19.86 \\
\hline 11 & 1.0850 & .5868 & .5562 & 29.05 \\
\hline 18 & 1.1820 & .5264 & .6556 & 6.30 \\
\hline 13 & 1.1250 & .5263 & .5987 & 9.92 \\
\hline 24 & 1.0675 & .5262 & .5313 & 33.40 \\
\hline 25 & 0.9740 & .5264 & .4476 & 58.40 \\
\hline
\end{tabular}

B.M.F. of Satureted Calomel electrode at $25^{\circ}$

oqual: 0.5266 volt.

Temperature coeficient: $0.0002 \nabla . /{ }^{\circ} \mathrm{C}$. 


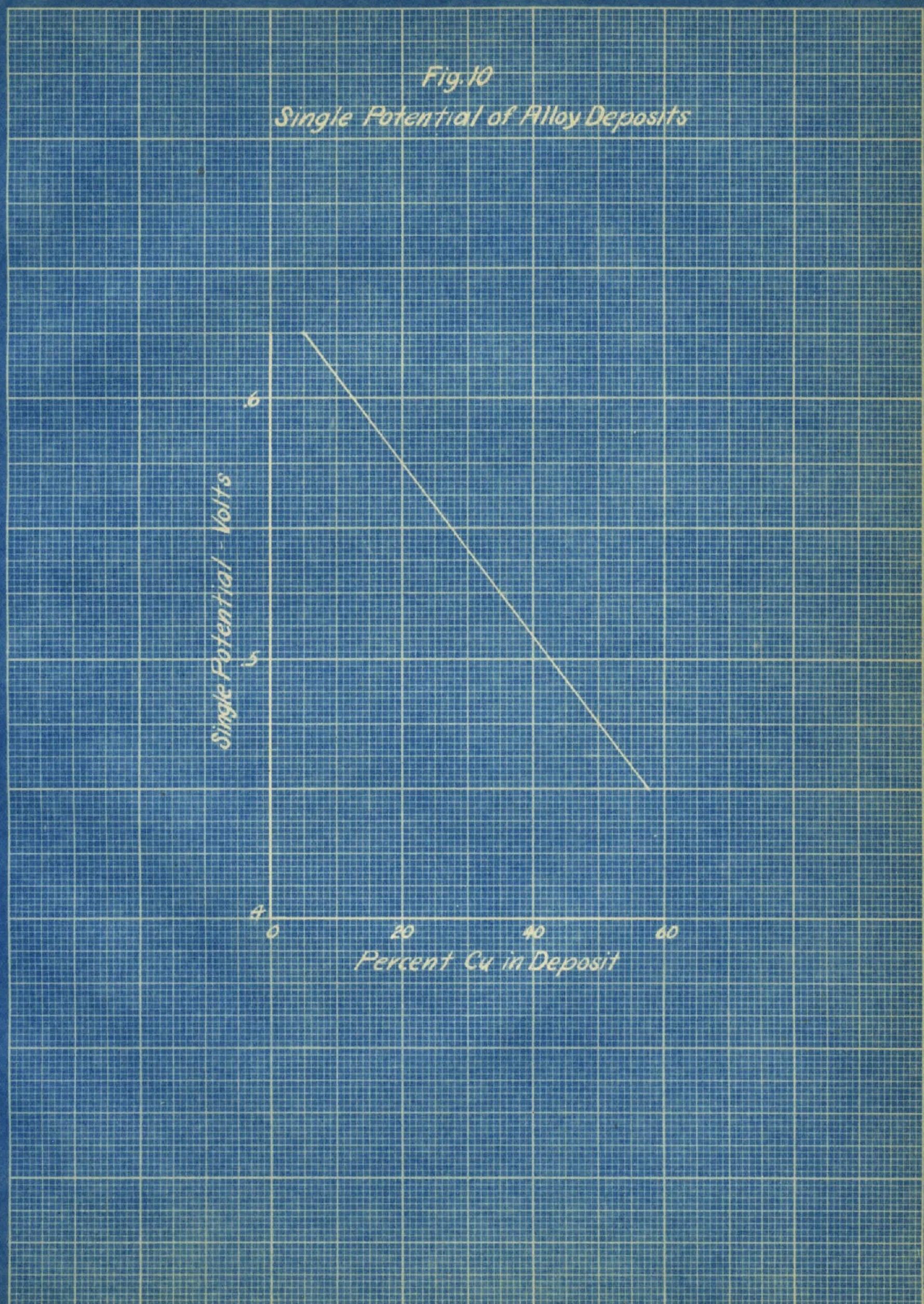




\section{Effeet of Potasalum Cyanlde}

Theory

The effect of KCI on the motal Ion concentration of the plating bath was rirat studied. An inoreave of the eyantde 100, $\mathrm{CH}^{-}$, ahould dedrense the secondary lontsation of the complex ejenide selts, as shown by the equation on Page 11, and thus decrease the concentration of the wotal 1ons. The lonization constants for the secondary Ionization of the complex copper salt la less then that for the complex cedratum walt wich supporta the fact that the concentration of copper lons 1 a decreased more rapidiy by the addition of the oyenide ion than that of the cadmivm ions. KCI ahould, therefore, reduce the copper content of the deposit. The experimental reaults agreo olosily wth the theoreticall facts as shown by the results given In Table VIII. Runs $A$ and $B$ were made ualng a bath of metal ratio of cu:0d of 60:40 while in the other runs a bath contalning $\mathrm{Cu}$ and $\mathrm{Cd}$ in the rat1o of $60: 20$ wes used. 
Table VIII

Rffect of Potassiun Cynnide

\begin{tabular}{|c|c|c|c|c|c|c|c|c|}
\hline \multirow{2}{*}{$\begin{array}{l}\text { Run } \\
\text { No. }\end{array}$} & \multicolumn{3}{|c|}{ Efflctencie: } & \multirow{2}{*}{$\begin{array}{l}\text { Percent } \\
\text { Copper }\end{array}$} & \multirow{2}{*}{$\begin{array}{l}\text { Total } \\
\text { KON }\end{array}$} & \multicolumn{3}{|c|}{ Potentlal with Current } \\
\hline & $\mathrm{Cu}$ & $\mathrm{cd}$ & Cathode & & & $\mathrm{Cu}$ & cd & Cathode \\
\hline A & 52.6 & 215.9 & 76.4 & 30.54 & 47.2 & 2.6286 & 0.8580 & 2.0870 \\
\hline B & 101.8 & 117.6 & 77.5 & 25.08 & 53.2 & 0.4625 & 0.8650 & 2.0375 \\
\hline c & 55.7 & 113.8 & 97.2 & 89.05 & 48.3 & -5.0615 & 0.6560 & 1.0000 \\
\hline D & 88.5 & $109 \cdot 4$ & 70.8 & 9.98 & 68.3 & -4.2280 & 0.8480 & 2.2375 \\
\hline E & 120.0 & 127.4 & 66.2 & 6.30 & 68.3 & 0.6440 & 0.8430 & 2.3456 \\
\hline
\end{tabular}




\section{Diacusaton}

P1gs, 11 and 12 show graphioally the varlous effects of the addition of kCH. The curves, while not being complete, show the trond of the offect. InereasIng the emount of froe eyanide increases the potentiel of the anodes and the cathode. Inereased polarization of the cathode ia accounted for by the fact that the equilibrium of the lonization of the complex salts (see page 11) 18 ahlfted toward the left reaulting in a decrease in motal 1ons. In order to deposit the copper and cadmiva a greater potential at the cathode is necessary then. The percontage of copper in the deposit decreases as the amount of KCl 1 s Inereased which is to be expected from the Incrensed cathode polarization. Anode offlolonolea Increses while the cathode efficteney decreases as the rosult of the suppression of Botal lons and the resulting inorease in cathode potential. oausing deposition of larger quantitles of hydrogon. 
|s|l|

Etrectot $\operatorname{RCN}$

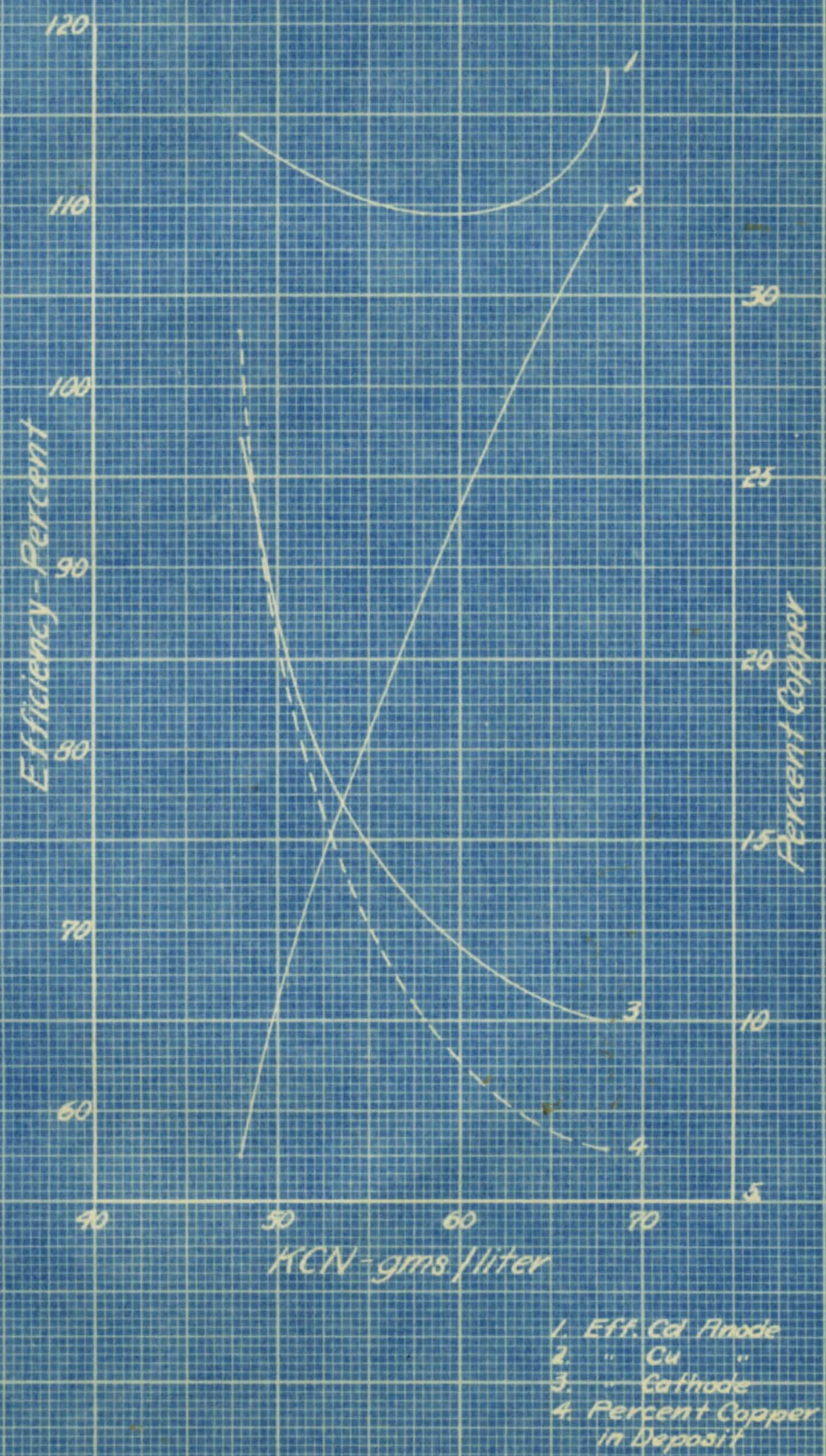




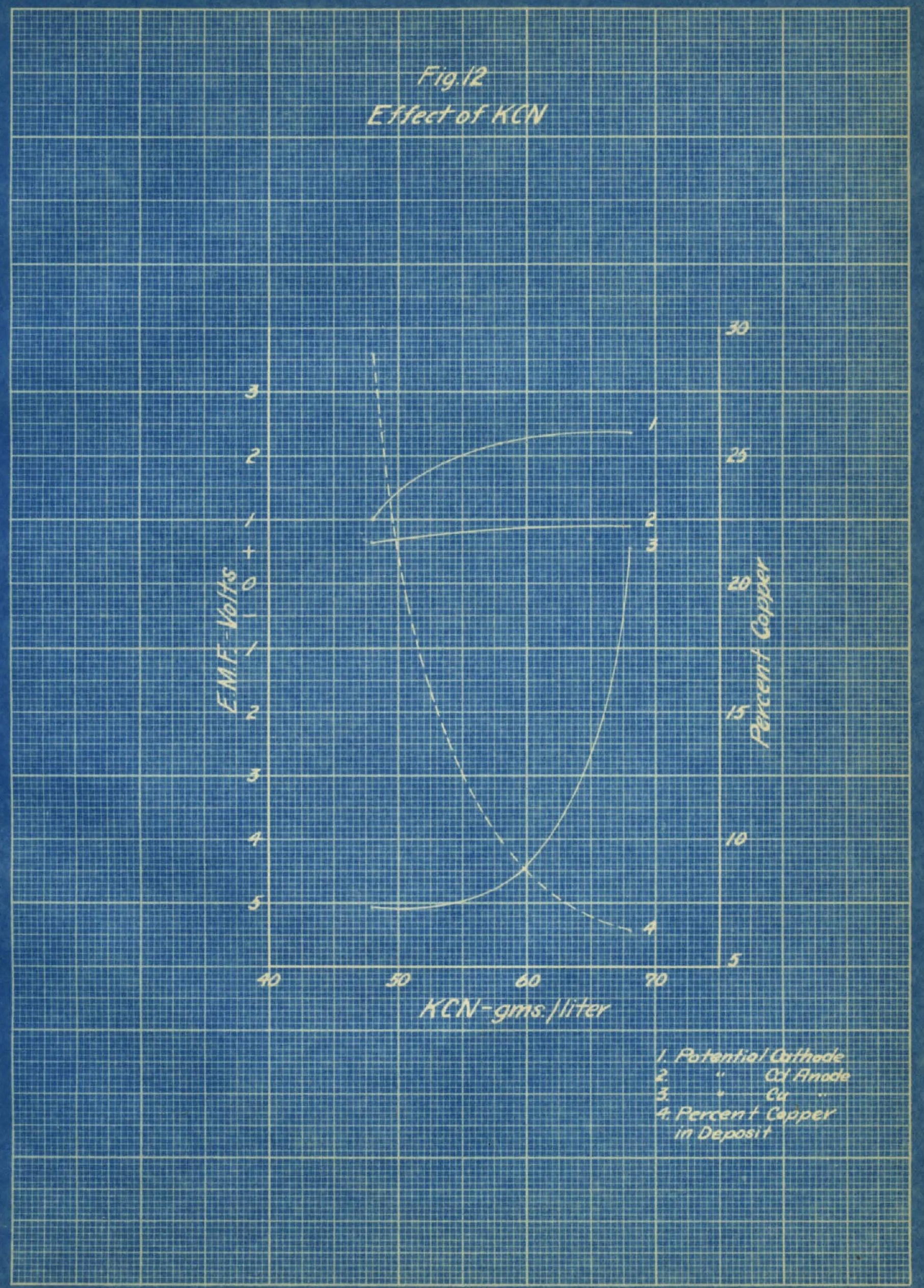


Refect of Sodium Blsulphite sddition

mooxy

A study of the various lonization equations of the copper and admitu complexes, page 1I, show that aold and alkeline aubstances should have a pronounced effeet on the concentration of metal lons and thus would influence the composition of the deposit. It is evident that an edaltion of an alkaline substance would force the reactions to the left, decressing the metril ion concontration and inoreasing the amount of undisaociated complex salt. Acld aubatanos, on the other hand, would force the reections to the right by reacting with the potassium hydroxide and forning the slightly dissoolated hydrocyanic acid and water. The concentretion of metal lons would be decreased from the greater dissociation of the complex salts. The atability of the copper and cadmin complex salts are dissimilar (seo page 12), that of copper being greator. The dissociation of the cadritu complex aslt thus proceeds more raplaly than that of the copper and the ratio of cadmitum to copper lon beoomes greater. The potential of copper approuches that of cedmiun as its lonic concentration decreases and it may even become more electro-negative than the cadmium. The ratio of the percent of copper to the percent of cadmium depostted is Increased as the potential of copper becomes equal to and becomes lower than that of cadmium as seen in PIg. 5 


\section{Experimontal Resulta}

The addition of sodium bisulphite we found to Inorease the copper content of the deposit. Table IX ahows the result: obtalned in a bath contalning copper and cadmivan in the ratio of $60: 20$.

Table IX

Erfect of Sodiun Blaviphite Addition

\begin{tabular}{|c|c|c|c|c|c|c|c|}
\hline \multicolumn{3}{|c|}{ Efriotencles: } & \multirow{2}{*}{$\begin{array}{c}\text { Pexeent } \\
\mathrm{Cu}\end{array}$} & \multirow{2}{*}{$\begin{array}{c}\mathrm{PaHSO}_{3} \\
\mathrm{~B} \cdot / 1 .\end{array}$} & \multicolumn{3}{|c|}{ Potential with Current } \\
\hline $\mathrm{Cu}$ & ca & & & & Cu & cad & Gath. \\
\hline 55.7 & 113.8 & & & 0.0 & -5.0615 & & \\
\hline & 115.0 & 79.4 & & 12.5 & -4.4230 & & 1.7100 \\
\hline 75.4 & 116.7 & 185.8 & 58.40 & 20.0 & -3.8075 & 0.4850 & 1.8730 \\
\hline
\end{tabular}

P1ga. 13 and 14 show the effect of sodiun b1sulphite on the efficioneles and potentials of the cathode and the anodes.

\section{Discueston}

Soditum bisulphtte is but alightly acld substance and Its acld propertiea should not be great enough to cause an Increase in the fowward raction to a very great degree. The reaction would proesed to completion if one of the products were removed from the reastion. Von Pechman and Manck (24) have shown that an adition product of the formina

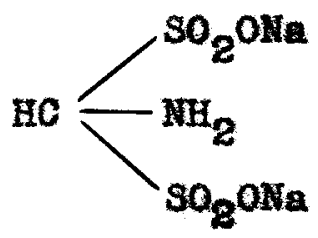




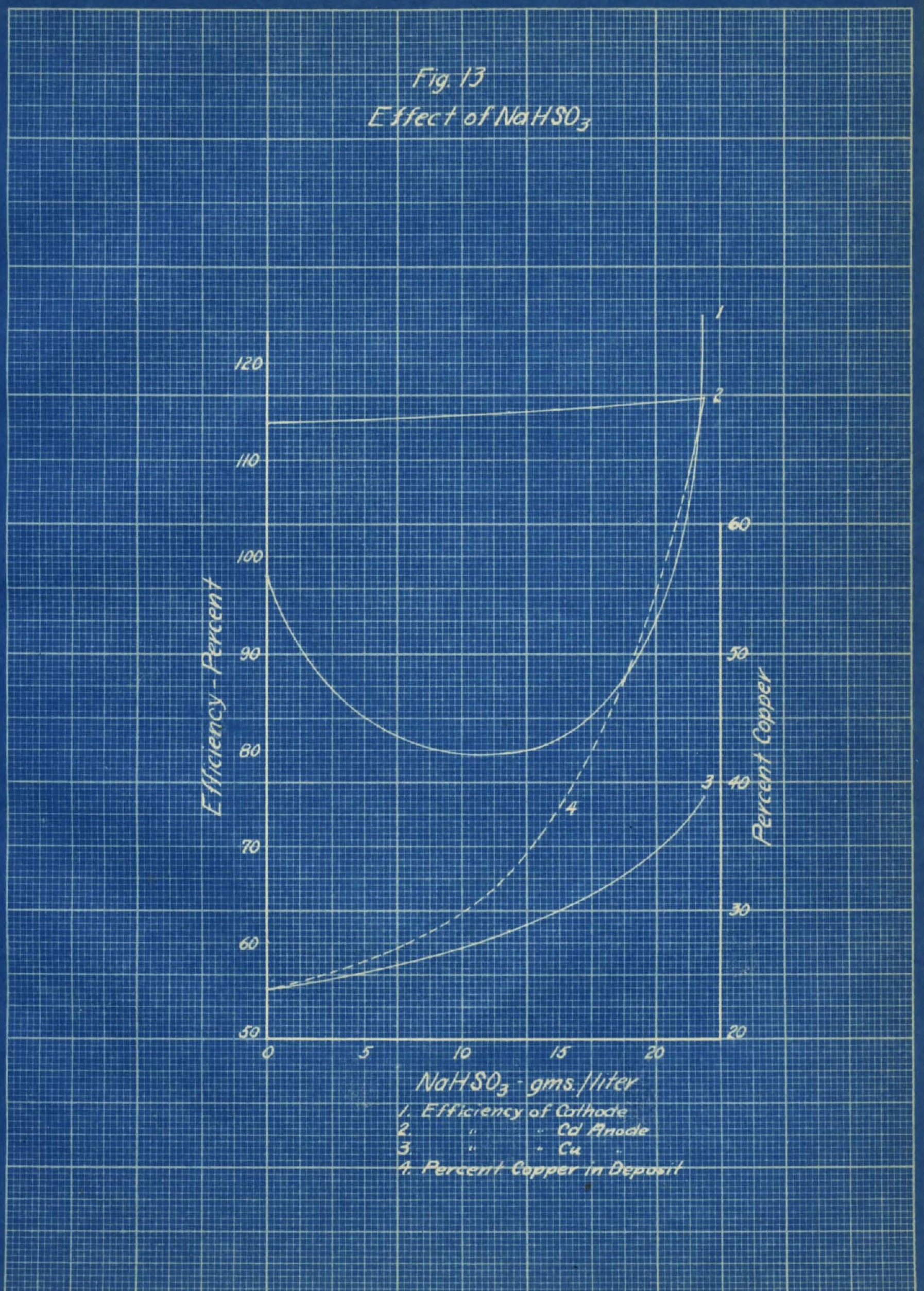




\section{fig. 14 \\ EX fect of NaHSOS}

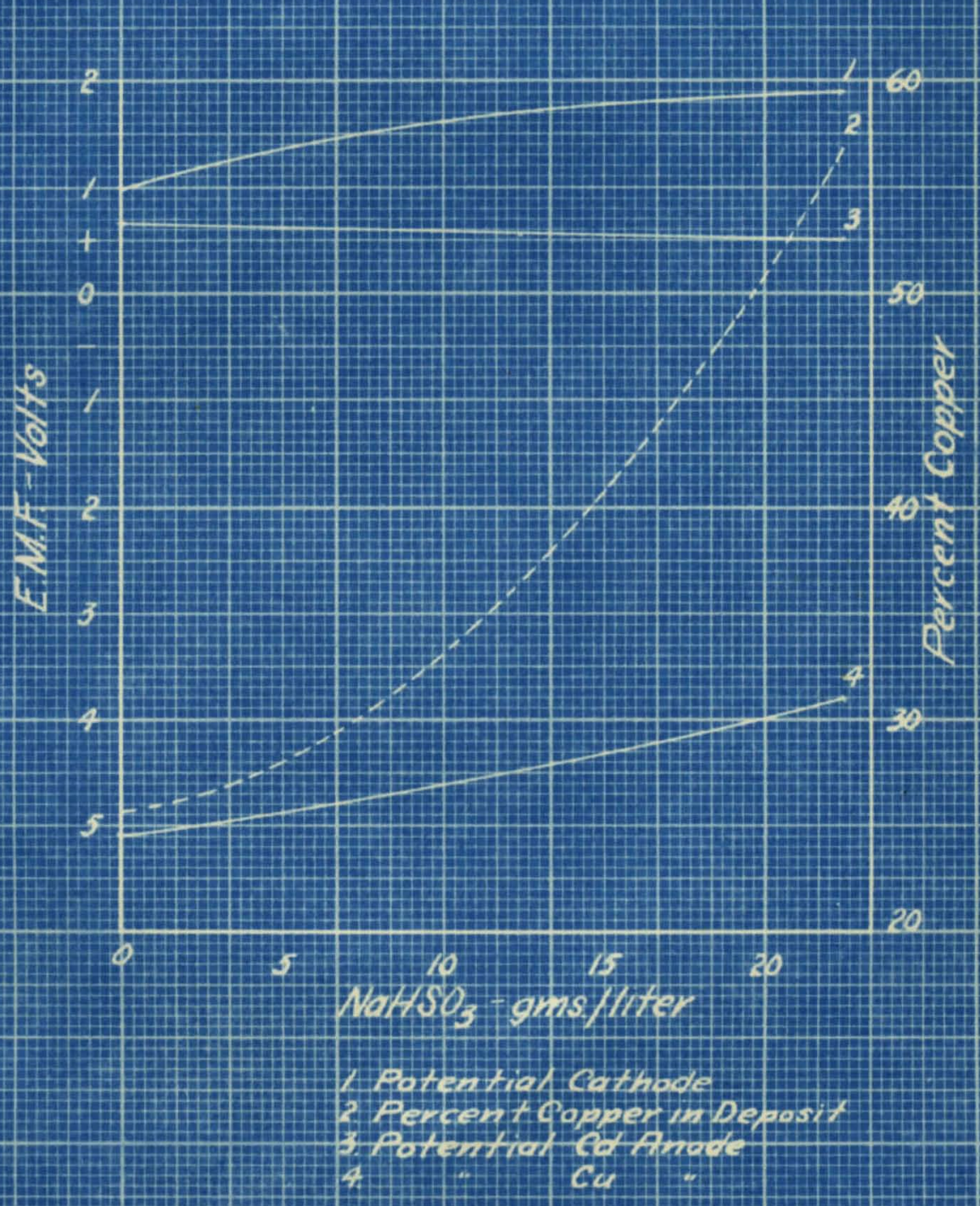


1s formed whon hydreeyante neld resats with sodium bioulphite. If this reaction is correct, the explanation of its effoct in inoreasing the percent of copper in the depost is roadily understood.

\section{Effect of Current Density}

A11 the runs were made using a eurrent density at the cathode of .3 ampere per square decineter. The effeet of increasing the current density was briefly studied and the results, as shom in Table $X$, show that an increase materially decreases the copper content of the deposit. Table X

Effect of Current Donsity

\begin{tabular}{|c|c|c|c|c|c|c|c|}
\hline \multicolumn{3}{|c|}{ Bffielencies } & \multirow{2}{*}{$\begin{array}{c}\text { Percent } \\
\mathrm{Cu}\end{array}$} & \multirow{2}{*}{$\begin{array}{l}\text { Current } \\
\text { Density }\end{array}$} & \multicolumn{3}{|c|}{ Potential with Current } \\
\hline $\mathrm{Cu}$ & cat & Cath. & & & $\mathrm{Cu}$ & Ca & Gath. \\
\hline 101.9 & 117.6 & 77.5 & 25.9 & 66.7 & 0.4685 & 0.9650 & 2.0575 \\
\hline 53.7 & 110.0 & 71.9 & 13.0 & 95.4 & 4.4760 & 0.8780 & 2.1635 \\
\hline
\end{tabular}

It amy be seen In Figs. 15 and 16 that the cathode potential Increases with the current density. This would cause the deposition of hydrogen and the baser motal, oadmiun, to take place in larger quantities, reaulting in docreased cathode offleloncy and a lower percentage of copper in the deposit. The ourves show this to be true. At the higher cprrent denatty the deposit is blistered and heavily streaked at the sides. 


$$
\begin{aligned}
& \text { Fig. } 15 \\
& \text { Effect of Current Density }
\end{aligned}
$$

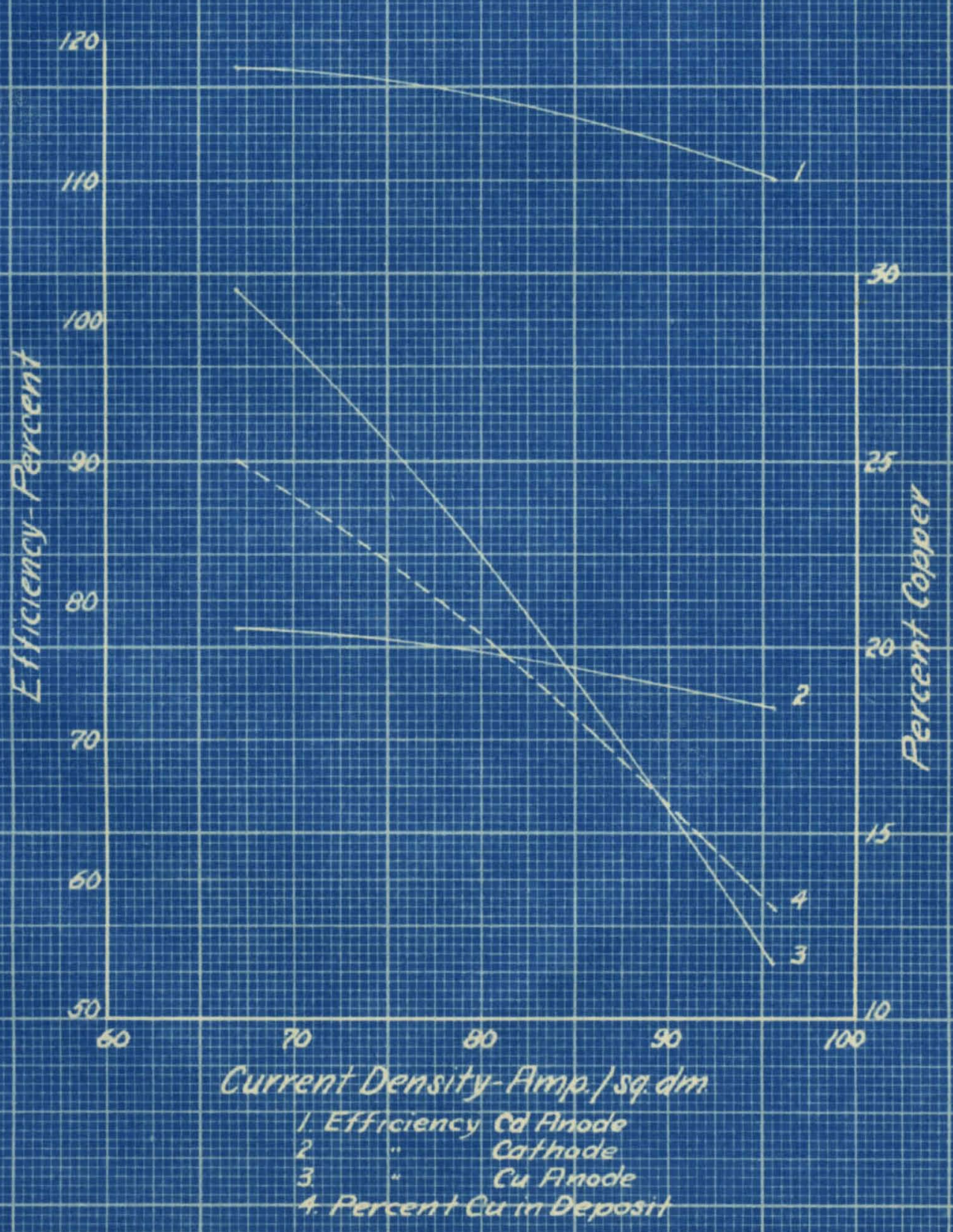




\section{Fas 15 \\ Effect of Current Density}

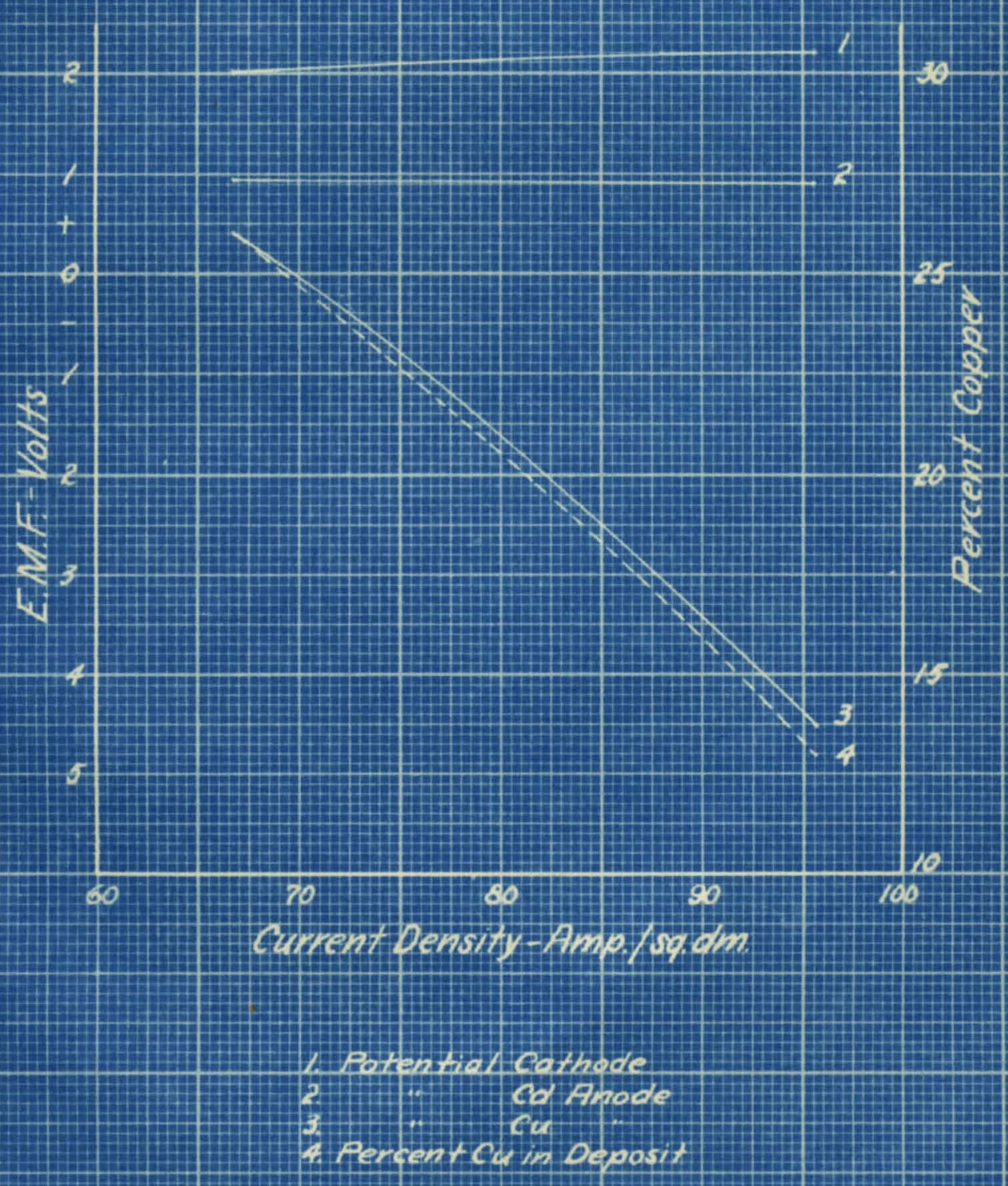


Bffect of Temperature

The temperature at wich the runs were rade was lept between 22 and $24^{\circ}$. An increase of temperature, It was thought, would Increase the percentage of copper In the depost atnoe there would be a more rapid diffuston of metal lons towards the cathode. In vestigations on the erfoet or tomperature in brass plating solutions (1) shows this to be true. The results given in the following table and In F1gs. 17 an 18 show that this is not the case in the simultaneous deposition of copper and cadmitun.

Table XI

Bfrect of Temperature

\begin{tabular}{|c|c|c|c|c|c|c|c|}
\hline \multicolumn{3}{|c|}{ Bfflatonotes } & \multirow{2}{*}{$\begin{array}{c}\text { Percent } \\
\mathrm{cu}\end{array}$} & \multirow{2}{*}{$\begin{array}{l}\text { Tomp. } \\
{ }^{\circ} \mathrm{c} .\end{array}$} & \multicolumn{2}{|c|}{ Potential with } & \multirow{2}{*}{$\begin{array}{l}\text { Current } \\
\text { Oath. }\end{array}$} \\
\hline $\mathbf{c u}$ & $\mathrm{cd}$ & fath. & & & $\mathbf{C u}$ & $\mathrm{cd}$ & \\
\hline 101.0 & 117.6 & 77.5 & 25.9 & 22 & 0.4625 & 0.9650 & 2.0375 \\
\hline 10.2 & 116.7 & 33.0 & 3.7 & 68 & 1.2125 & 0.9000 & 1.4445 \\
\hline
\end{tabular}

The effictency of the cathodo and anode rapidy decrease with increased temperature which any bo explained by the Increased chomical solubility of the retals and alloy in the plating solution at hlgher temperature. The potential of the cathode decreases, but the percentage of copper in the deposit also fella off rapidiy. 


\section{Fig 17 \\ Elfect of Temperature}

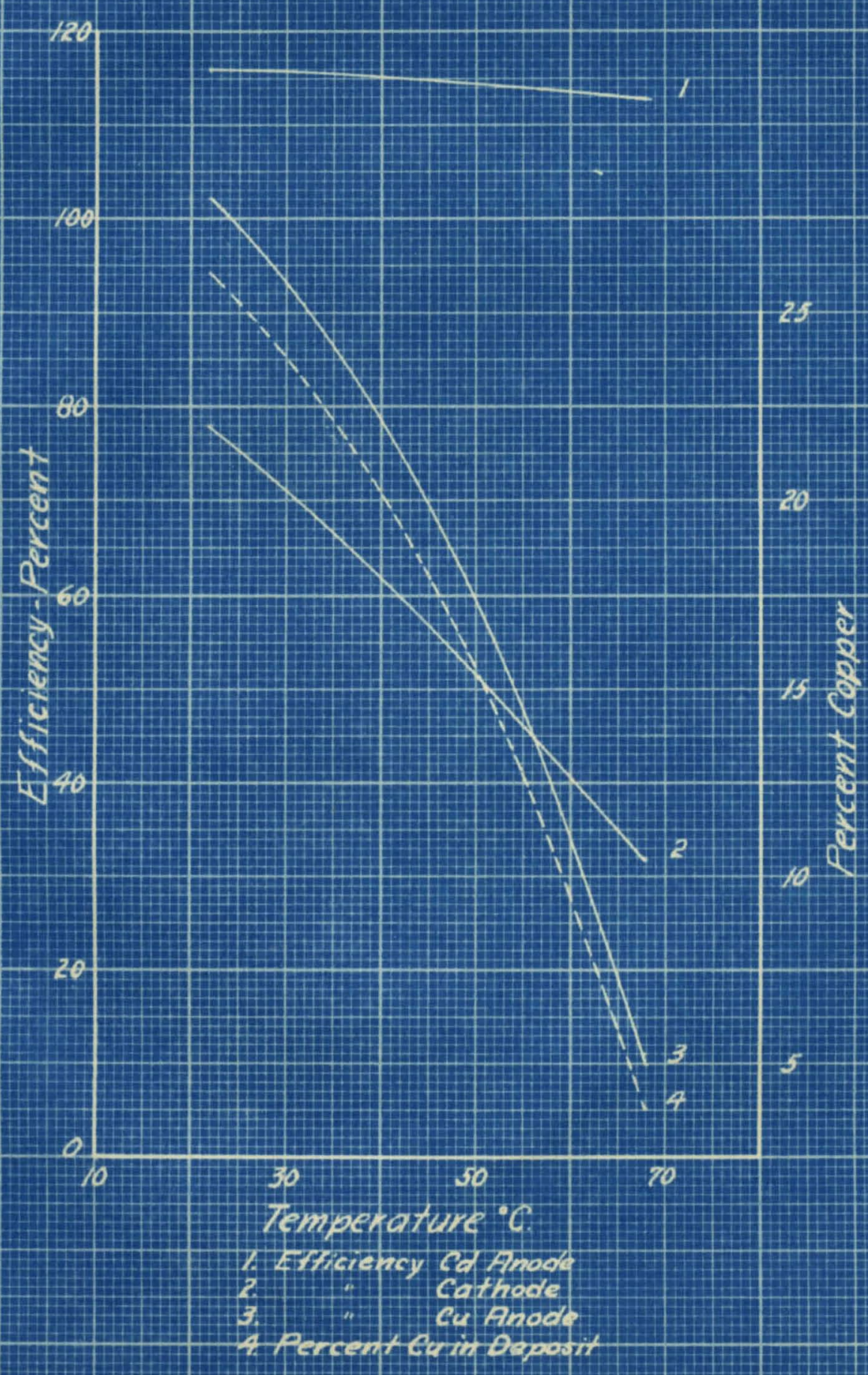




\section{F19. 18 \\ Effect of Temperature}

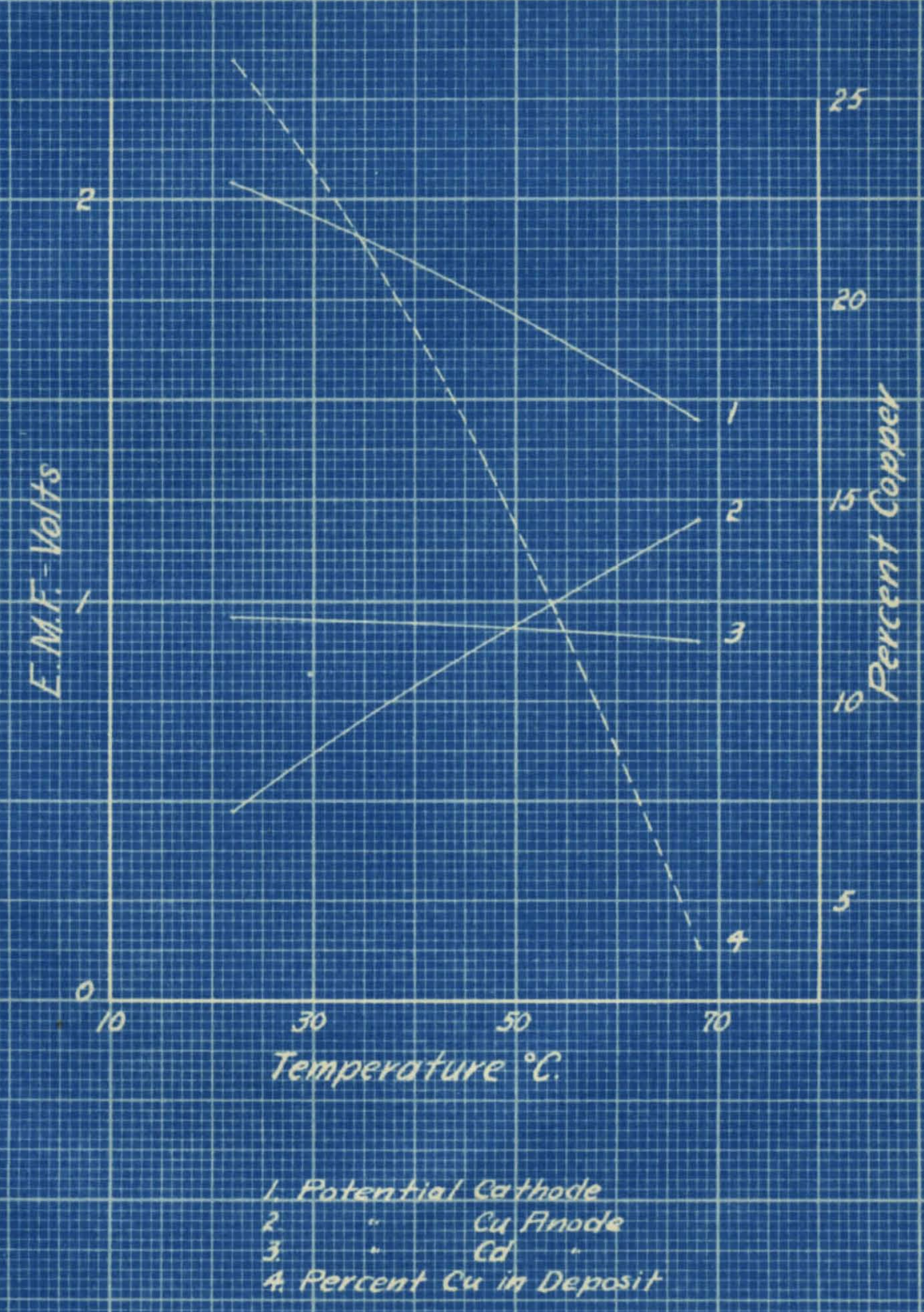




\section{Bffect of Dilution}

The effoct of a deorrave in mota 3 ion content, 1.e. dilution, was brierly studied. Table XII and FIge. 19 and 20 show that the peroent of oopper In the deposit decreanes as well as the electrode efficlenolos.

Pable XII

Efroot of Dilution

\begin{tabular}{|c|c|c|c|c|c|c|c|}
\hline \multicolumn{3}{|c|}{ Efflotenote: } & \multirow{2}{*}{$\begin{array}{c}\text { Percent } \\
\mathrm{cu}\end{array}$} & \multirow{2}{*}{$\begin{array}{c}\text { Wetal } \\
\text { Content }\end{array}$} & \multicolumn{2}{|c|}{ Potential with } & \multirow{2}{*}{$\frac{\text { Current }}{\text { Cath. }}$} \\
\hline $\mathrm{Cu}$ & ca & Dath. & & & $\mathrm{Cu}$ & cd & \\
\hline 101.9 & 117.6 & 77.5 & 85.9 & $20 \mathrm{~g} \cdot / 1$ & 0.4685 & 0.9650 & 2.0575 \\
\hline 62.6 & 118.8 & 63.5 & 21.9 & 15 & 4.4865 & 0.9040 & 2.1255 \\
\hline
\end{tabular}




\section{Fig: 19 \\ Effect of Metal content}

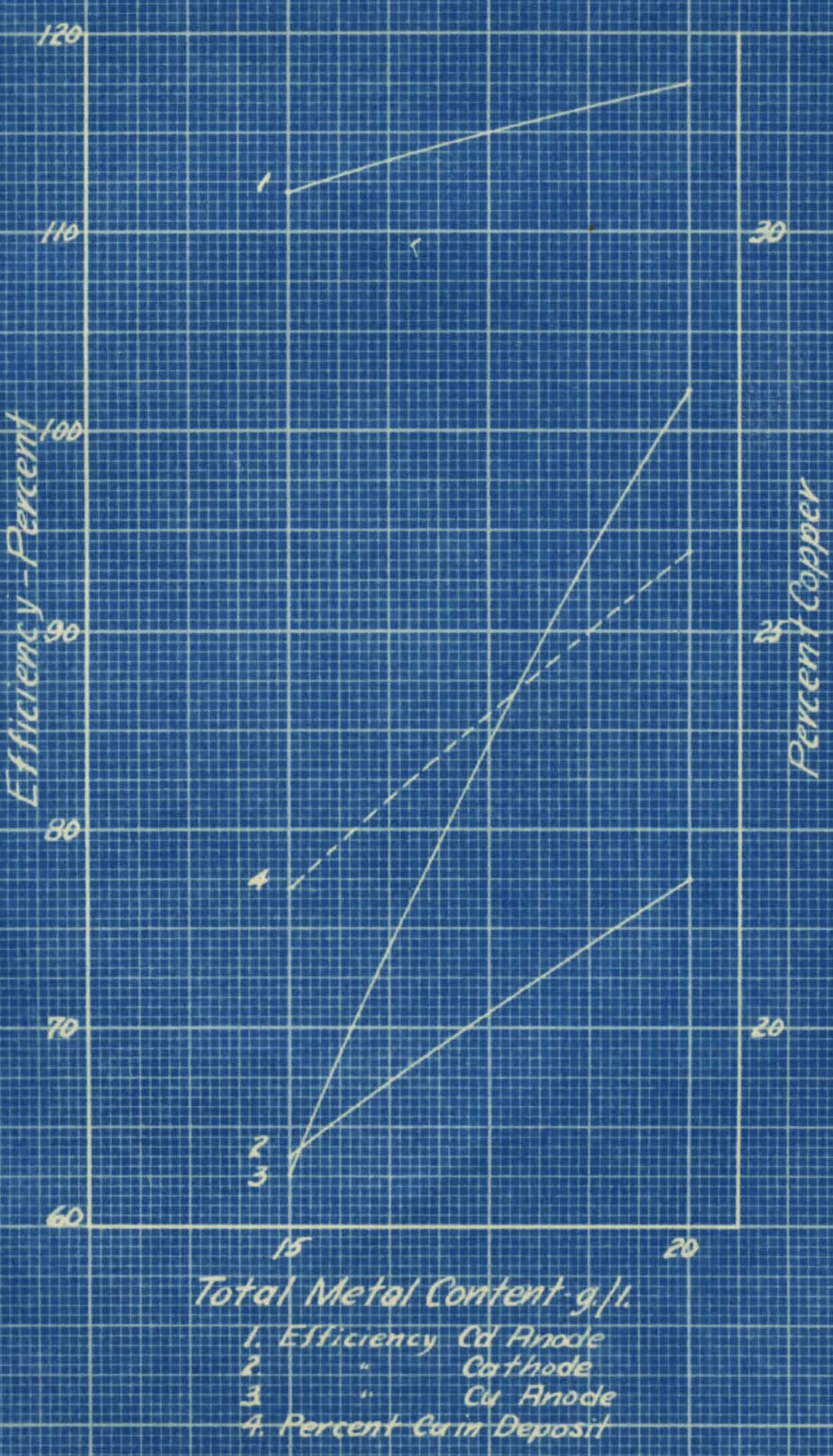




\section{9,20 \\ Effectof Metol content}

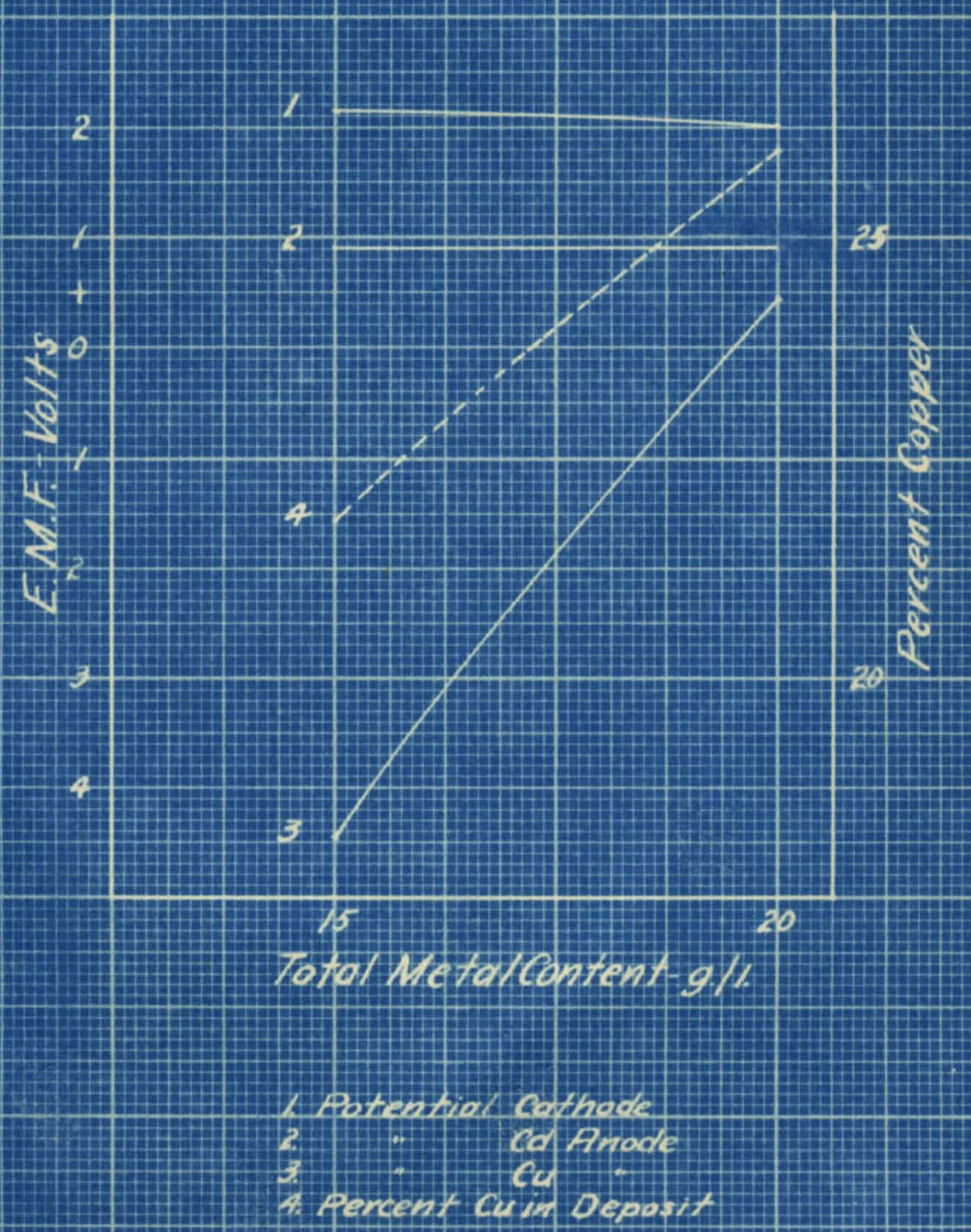




\section{Sumonary}

1. It has been shom that it is possible to - eloctrodoposit a copper-cedmium alloy containing 58.4 percent copper, which should make the alloy more resiatant to corrosion than elther of the pure motals.

8. A plating bath contuining $\mathrm{cu}$ and $\mathrm{Cd}$ in tho ratio of 60:20 and a total metal ion content of $20 \mathrm{grams}$ per liter wth $\mathrm{NaHSO}_{3}$ as an addition agent is recommended for the deposition of the alloy of 58.4 percent copper and 41.6 peroent cadmitum. The mintmum amount of excess KCN should be ueed.

3. The effect of varlations in temperature, current density, dilution, excess KCN, and amount of $\mathrm{NaHSO}_{3}$ an the copper content of the deposit has been studiod. 


\section{BLblegraphy.}

1. Ferguson and sturdevant, Trane, An. Eleot. S00., 1980.

8. Watte, Eleotroohemiotry, MoGruw fil21 Go., lat. Rat., 204, 1014

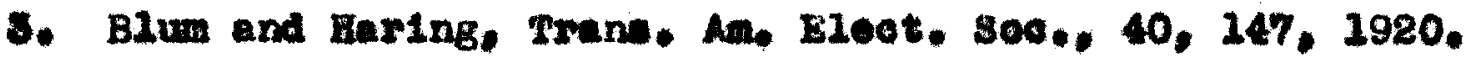

4. Watts, Bloctroohomistry, lot. Eat,o 97, 1214.

6. Told, 98

6. Sohoh, Trans, Am. Eleot, Soc., 11, 135-61

7. Watte, Flectrooinondotg, lat, Fdt, 114, 2914.

8. rold, 124. Engliah Pat. No. 1802 ar 1898

9. Tola, 65.

10. IJId, 213.

22. To24, 224.

18. Tb1d, 215 .

23. Private comunieation from a Dseertiation by Frnst end renn on the Lootromeposited syst on Cu-Cd-zn.

14. N. A. Pushin, J. Ruse, Phys, Chem, soc., 39, I3.

15. Jonktns ono Henson, Inst, of NetalB, 51, 2E7, 1924.

16. Chem, and Met, Fng, Hov, 1926, 671.

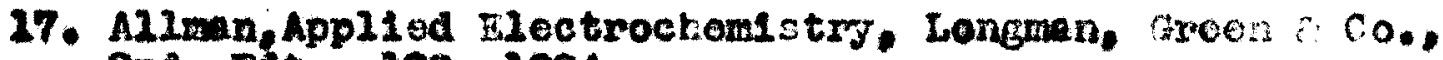
8nd. Bat., 128, 2024.

18. Blum and Hogaboem, Princlples of Ilectropiating. Mocraw H121 Co., Ist. Edit., 344, 1984.

19. Classen and finl1, John W1ley and Sons, 79, 2913, 80. 8001

12. Fo kunohext, ze1te, Inorg, Chem, 2004, 42, 337

82. 300.19.

28. Ib14, 80 ot. seq.

24. Ber, douten, ohom, Goe., 28, 2374, 1895, Also Jowmel of Fhysloal Chemlatry, 180, 1025. 


\section{ABPOBIOCRAPHY}

Borm February 30, 1906 at Ogleabie, Illinols. Attended gramer school in treeport, IIl., Los Angles, Callfornia, and Minneapolis, Minn.

Was graduated from Central High Sohool, MInneapol1s, in December 1928.

Attended the Unifersity of Minnesota, Jenuary 1923 to June 1926, recelving the B.S, degree in Chemlcal Engineering.

From September 1926 to June 1927, was Assistant In Chemintry at the University of Loulavilie.

Left the $\mathrm{U}$. of L. to become Researah Chemical Ingineer at the Atrospherio N1trogen Corporation, Syracuse, W. Y.

Wes tranaferred from Syrecuse to the Hopewe11, Virginia plant for construction work, later assuning the duties of supervisor of Instruments.

Rosignod position at Hopewell to become Associate Phyalcal Chomint at the D. S. Bureau of Mines, Amarillo, Texas In June 1931.

Married MLs WIIma James Davis in 1928. 